\title{
Mineral Surfaces, Geochemical Complexities, and the Origins of Life
}

\author{
Robert M. Hazen ${ }^{1}$ and Dimitri A. Sverjensky ${ }^{2}$ \\ ${ }^{1}$ Geophysical Laboratory, Carnegie Institution of Washington, Washington, DC 20015 \\ ${ }^{2}$ Department of Earth and Planetary Sciences, Johns Hopkins University, Baltimore, Maryand 21218 \\ Correspondence: rhazen@ciw.edu
}

Crystalline surfaces of common rock-forming minerals are likely to have played several important roles in life's geochemical origins. Transition metal sulfides and oxides promote a variety of organic reactions, including nitrogen reduction, hydroformylation, amination, and Fischer-Tropsch-type synthesis. Fine-grained clay minerals and hydroxides facilitate lipid self-organization and condensation polymerization reactions, notably of RNA monomers. Surfaces of common rock-forming oxides, silicates, and carbonates select and concentrate specific amino acids, sugars, and other molecular species, while potentially enhancing their thermal stabilities. Chiral surfaces of these minerals also have been shown to separate left- and right-handed molecules. Thus, mineral surfaces may have contributed centrally to the linked prebiotic problems of containment and organization by promoting the transition from a dilute prebiotic "soup" to highly ordered local domains of key biomolecules.

$\mathrm{T}_{\mathrm{p}}^{\mathrm{h}}$ he question of life's origin is in essence a problem of information transfer from a geochemical environment to a highly localized volume. Earth's prebiotic environment possessed a varied inventory of raw materials - an atmosphere, oceans, rocks and minerals, and a diverse suite of small organic molecules. The processes by which the Hadean Earth was transformed to a living world required the selection, concentration, and organization of specific organic molecules into successively more information-rich localized assemblages. In this view, life's origins can be modeled as a problem in emergent chemical complexification (Morowitz 1992; de Duve 1995; Lahav 1999; Hazen 2005; Zaikowski and Friedrich 2007).
At least five aspects of Hadean geochemical environments contributed to Earth's prebiotic complexity and thus may have played significant roles in the emergence of life.

1. Chemical Complexity: The simplest chemical models for life's origins use only four essential elements-C, H, O, and N (e.g., Oparin 1938; Urey 1951; Morowitz 1992; Morowitz et al. 2000)—with the possible addition of S (Wächtershäuser 1990; de Duve 1995) and/or P (Westheimer 1987; Kornberg et al. 1999). Experiments to probe origins-of-life chemistry have often used correspondingly simple chemical systems (Miller 1953; Fox and Harada 1958; Oró 1961; Sanchez et al.

Editors: David Deamer and Jack W. Szostak

Additional Perspectives on The Origins of Life available at www.cshperspectives.org

Copyright (C) 2010 Cold Spring Harbor Laboratory Press; all rights reserved; doi: 10.1101/cshperspect.a002162

Cite this article as Cold Spring Harb Perspect Biol 2010;2:a002162 
R.M. Hazen

1967; Shapiro 1988; Hennet et al. 1992; Marshall 1994; Eschenmoser 1999; Bernstein et al. 2002). Geochemical environments, in contrast, typically incorporate a dozen or more major and minor elements, with dozens more trace elements (Turekian 1968; Albarède and Hoffmann 2003; McSween et al. 2003; Steele et al. 2009). Therefore, it is important to consider the roles of a wider chemical spectrum in essential prebiotic reaction pathways.

2. Interfaces: Even given the most optimistic assessments of exogenous and endogenous sources of prebiotic organic molecules (Chyba and Sagan 1992), the Hadean oceans or large terrestrial bodies of water would have been extremely dilute (Pinto et al. 1980; Stribling and Miller 1987; Cohn et al. 2001). Mechanisms for the selection and concentration of essential biomolecules are thus required. In this regard, numerous authors have focused on the effectiveness of interfaces between minerals and aqueous solutions (Goldschmidt 1952; Cairns-Smith and Hartman 1986; Lahav 1994; Ertem and Ferris 1996; Ferris 1999, 2005; Ertem 2002; Schoonen et al. 2004; Hazen 2006), or among immiscible fluids (Lasaga et al. 1971; Deamer and Pashley 1989; Morowitz 1992; Dobson et al. 2000; Tuck 2002; Monnard et al. 2002). Such surfaces provide loci where organic molecules can be selected and concentrated from more dilute solutions.

3. Gradients: Gradients were important disequilibrium features of the Hadean Earth. Thermal gradients were sustained both by solar radiation and by geothermal heat, whereas chemical gradients were produced by mineral dissolution and the mixing of different fluid reservoirs. Thermal and chemical gradients are striking characteristics of hydrothermal systems, both on the deep ocean floor and in near-surface continental environments. At modern-day deep sea hydrothermal vents, for example, thermal gradients may reach $300^{\circ} \mathrm{C}$ at scales of a few centimeters, whereas significant gradients in $\mathrm{pH}$, oxidation state, and in dissolved cationic and anionic species occur at scales significantly less than a meter (Shock 1992; Carl 1995; Van Dover 2000; Kelley et al. 2005). Less severe gradients also occur at off-axis hydrothermal systems, and during mixing of fluids of differing salinities, for example where river waters enter the oceans.

4. Fluxes: The dynamic circulation and mixing of fluids through such varied processes as hydrothermal venting, ocean currents, stream and groundwater flow, winds, and tides is another ubiquitous disequilibrium feature of Earth's near-surface environment.

5. Cycles: The prebiotic geochemical characteristics perhaps most critical for life's origins were pervasive cycling of environmental conditions at or near Earth's Hadean surface. Periodic cycles such as day-night, high tidelow tide, hot-cold, and wet-dry subjected prebiotic chemicals to repeated selective pressures and thus winnowed the pool of available chemical species. Episodic events, including asteroid impacts and volcanic eruptions, added additional selective pressures to the near-surface organic inventory.

These five geochemical characteristics must be considered individually and collectively in origins-of-life models. This article focuses primarily on just one of these aspects, the possible roles of crystalline surfaces of common rockforming minerals, which provided ubiquitous crystal-fluid interfaces for a variety of molecular processes. The mineral-water interface is a dynamic, energetic environment that can selectively adsorb biomolecules, increase the thermal stability of organic species, promote chemical reactions, and facilitate the type of molecular concentration and organization that must have preceded life's origins.

\section{BACKGROUND}

Chemical interactions at crystal-water interfaces are crucial to a wide range of scientific and technological topics, including corrosion, heterogeneous catalysts, chemical sensors, teeth and bones, titanium implants and other prosthetic medical devices, and myriad commercial 
products including paints, glues, dyes, lubricants, solvents, and cleaners. Geochemists pay special attention to reactions between mineral surfaces and aqueous species-interactions central to weathering, soil formation, hydrothermal ore-forming fluids, biomineralization, biofilm formation, uptake and release of chemicals that affect water quality, and many other natural processes (Davis and Kent 1990; Stumm 1992; Vaughan 1995; Hochella 1995; Drever 1997; Langmuir 1997; Brown et al. 1998; Brown and Parks 2001; Davis et al. 2004; De Yoreo and Dove 2004; Lee et al. 2006, 2007; Glamoclija et al. 2009). Studies of mineral-molecule interactions related to origins of life build on this vast geochemical literature.

\section{On the Nature of Mineral Surfaces}

The idealized crystalline surface terminates in an arrangement of atoms that approximates the planar truncation of a periodic threedimensional crystal structure (Fig. 1A). In real crystals this ideal situation is altered in several ways (e.g., Hochella and White 1990; Somorjai 1994; Hochella 1995; Vaughan 1995; Brown et al. 1998). First, surface atoms reside in an environment quite different from those below the surface, and thus undergo relaxation owing to boundary effects-typically slight deviations from their formal crystallographic positions (Hochella 1990; Stipp and Hochella 1991;
Wright et al. 2001). Second, mineral surfaces in air or an aqueous medium are commonly subject to chemical alteration through oxidation, hydration, or hydroxylation (Guevremont et al. 1998; Biino et al. 1999; Stipp 2002). Third, crystals invariably have defects and impurities that alter local surface physical properties and chemical reactivity (Hochella 1990; Cygan et al. 2002).

The topology of real crystal surfaces also represents an important deviation from ideality because crystal surfaces are seldom flat. In the intensively studied case of cubic close-packed metal surfaces, including $\mathrm{Pt}, \mathrm{Ag}, \mathrm{Au}$, and $\mathrm{Cu}$, ideally flat terraces can only exist for (100), (110), and (111). All other surfaces of these metals must incorporate steps and/or kinks (Fig. 1B and C). Kink sites are intrinsic to all high-index surfaces, whether on metals or minerals, and they dictate molecular adsorption behavior on these faces (McFadden et al. 1996; Sholl 1998; Power and Sholl 1999; Ahmadi et al. 1999; Gellman et al. 2001).

Mineral surfaces, with their lower symmetries and multiple crystallographically distinct atomic sites, present additional complexities compared with metals (Lasaga 1990; Hazen 2004). Although some common surfaces of rock-forming minerals can be ideally planar at the atomic scale (e.g., the [100] plane of quartz $\left[\mathrm{SiO}_{2}\right]$, the [001] planes of graphite [C] and molybdenite $\left[\mathrm{MoS}_{2}\right]$, and the [001] planes of varied layer silicates such as micas and
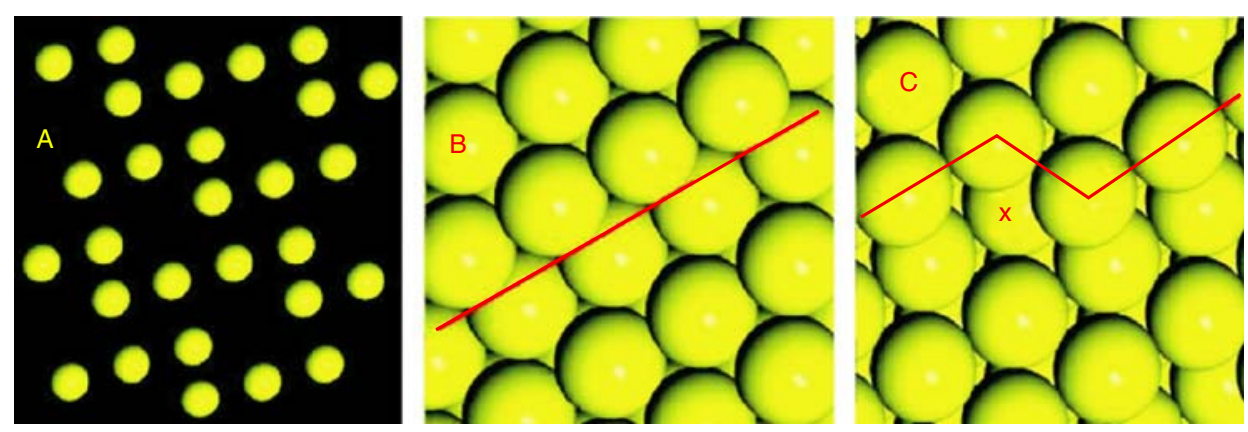

Figure 1. Crystal surfaces display a variety of atomic surface features. $(A)$ The surface of an ideal crystal may be represented as a periodic two-dimensional arrangement of atoms; these atoms may be coplanar or they may occur at slightly different heights. Real crystals feature surfaces that are typically stepped $(B)$ or kinked $(C)$. Kink sites provide chiral (left- or right-handed) centers (X). Experimental and theoretical studies reveal that molecular adsorption is enhanced at such surface irregularities. 
R.M. Hazen

A

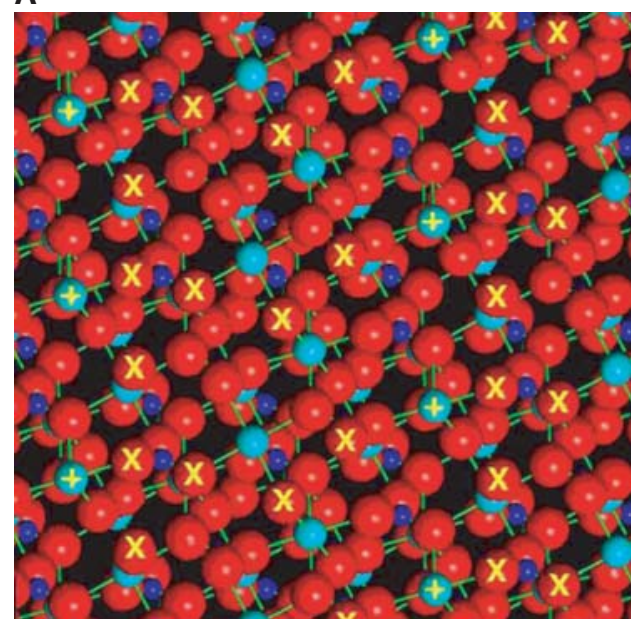

B

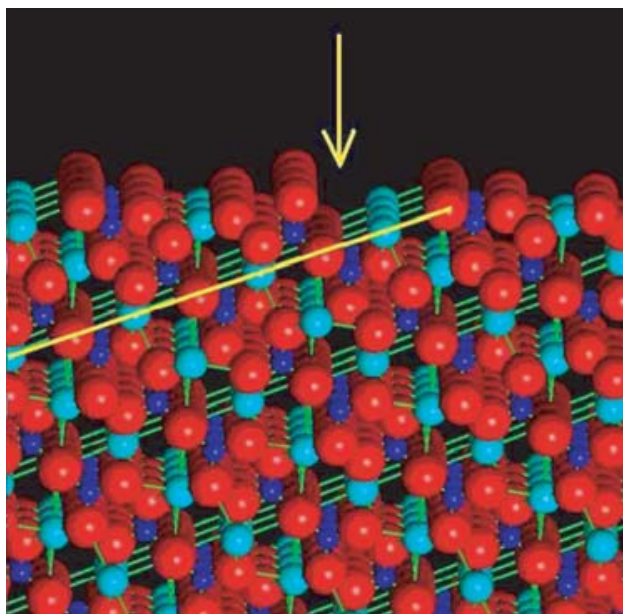

Figure 2. The common calcite form of $\mathrm{CaCO}_{3}$ often displays chiral surfaces. (A) The structure of the (21-34) face of calcite features a chiral arrangement of positive $(+)$ and negative $(\mathrm{X})$ charge centers near the crystal termination. $\mathrm{Ca}, \mathrm{C}$, and $\mathrm{O}$ atoms are turquoise, blue, and red, respectively. In this $20 \times 20 \AA$ view the (01-8) axis is vertical - an orientation that provides a useful image of the surface structure. (B) A view of this surface tilted $3^{\circ}$ from horizontal (projected almost down the [01-8] axis) reveals the irregular surface topology, including 2- $\AA$-deep steps (yellow arrow) that result from the oblique intersection of layers of $\mathrm{Ca}$ and rigid $\mathrm{CO}_{3}$ groups with the surface (yellow line).

chlorites), most surfaces are intrinsically irregular, as shown by the $\sim 2 \AA$ relief on the common (21-34) surfaces of calcite $\left(\mathrm{CaCO}_{3}\right)$ (Fig. 2) (Hazen 2004). Mineral surfaces also commonly incorporate growth defects, including step edges and kink sites, which provide promising docking loci for organic molecules (Lasaga 1990; Teng and Dove 1997; Teng et al. 1998; Orme et al. 2001; Hazen and Sholl 2003; De Yoreo and Dove 2004). For example, Teng et al. (2006) showed the stepdependent adsorption of succinic acid (1,4-dicaboxlyic acid) on irregular (10-14) growth surfaces of calcite. The presence of succinic acid in solution blocks certain growth directions and thus dramatically modifies calcite surface growth morphology.

Additional complexities arise from a variety of geological materials that do not have periodic two-dimensional surfaces, notably amorphous materials such as basaltic glass from seafloor volcanoes. Mesoporous zeolites and nanoparticulate clays (including layer phyllosilicates and hydroxide minerals) interact with organic molecules in complex three-dimensional environments (Smith 1998; Greenwell and Coveney 2006; Benetoli et al. 2007). For example, Pitsch et al. (1995) showed that double-layer hydroxide minerals such as hydrotalcite efficiently adsorb glycoaldehyde phosphate and formaldehyde, presumably into their relatively spacious inter-layer regions, and promote condensation reactions to tetrose and hexose sugar phosphates. Given these complexities, any realistic modeling of interactions between biomolecules and mineral surfaces must take into account the geometries of both molecules and surfaces.

\section{On the Nature of the Mineral-Water Interface}

Mineral surfaces undergo significant modifications in an aqueous environment, especially in an electrolyte solution such as sea water (Parks 1990; Davis and Kent 1990; Van Cappellen et al. 1993; de Leeuw and Parker 1997; de Leeuw et al. 1999; Wright et al. 2001; Stipp 2002). In the classic electrical double layer (EDL) model, a crystal surface in pure water directly contacts a compact quasi-periodic layer of $\mathrm{H}^{+}$or $\mathrm{OH}^{-}$ ions, whereas a second diffuse layer of mobile ions extends from the compact layer a few Angstroms into the fluid. The nature of the 
EDL is strongly dependent on $\mathrm{pH}$ : At lower $\mathrm{pH}$, the surface is typically protonated and thus positively charged, whereas at higher $\mathrm{pH}$, the surface is negatively charged with hydroxyls. The crossover $\mathrm{pH}$ at which the surface is electrically neutral is called the point of zero charge $\left(\mathrm{pH}_{\mathrm{PZC}}\right)$.

It is important to recognize that crystallographically distinct faces on the same crystal will have different surface structures, and thus may have significantly different $\mathrm{pH}_{\mathrm{PZC}}$, surface reactivities, and other properties (Guevremont et al. 1998; Hung et al. 2003; Churchill et al. 2004). For this reason, powdering a crystal sample to increase the reactive surface area in an experiment may destroy significant information regarding specific reaction mechanisms associated with specific crystallographic faces (Hazen 2006).

\section{On the Nature of Mineral-Molecule Interactions}

Adsorbed ionic and molecular species modify the electrical double layer of mineral surfaces by displacing $\mathrm{OH}^{-}, \mathrm{H}^{+}$, and $\mathrm{H}_{2} \mathrm{O}$ at the solidfluid interface. Recent developments in surface complexation modeling enable accurate modeling of surface speciation. Sverjensky and Fukushi (2006) developed an extended triple-layer (ETL) model to account for the process of inner-sphere surface complexation by ligand exchange. The ETL model treats a previously neglected phenomenon integral to ligand exchange reactions: the electrostatic work during desorption of water dipoles from a charged surface. The magnitude of this work is substantial and depends only on the stoichiometry of the surface reaction. When structures of adsorbed anions established in spectroscopic studies are used to calibrate an ETL model of bulk adsorption data, the model can independently predict proportions of innerto outer-sphere surface complexes as functions of $\mathrm{pH}$, ionic strength, and surface coverageproportions that have been confirmed in experiments, for example in studies of aspartate and glutamate adsorption on titanium dioxide (e.g., Jonsson et al. 2009).

More than a century of experimental and theoretical research has explored the interaction of dissolved aqueous chemical species with mineral surfaces (for reviews see, e.g., Parsons 1990; Hochella and White 1990; Brown et al. 1998). Most of this extensive literature focuses on dissolved ions and inorganic complexes; however, many of the principles developed for mineralion interactions also apply to biomolecules.

All surface-promoted reactions require at least one molecular species to interact with the surface. These interactions can be mediated by water molecules, protons, or hydroxyl groups through relatively weak interactions (outersphere adsorption, or "physisorption"). Alternatively, one or more chemical bonds can form (inner-sphere adsorption, or "chemisorption"). Chemisorbed ions typically bond to one or two surface atoms, whereas larger molecules can adopt a variety of surface topologies with multiple attachments (Fig. 3), as discussed later in this article (Davis and Kent 1990; Zhang et al. 2004; Sverjensky et al. 2008; Jonsson et al. 2009).

Details of molecular adsorption are dependent on several variables, most notably $\mathrm{pH}$, the nature and concentrations of molecular solutes, and the identities and concentrations of electrolytes (Schindler 1990; Sverjensky 2005; Sverjensky and Fukushi 2006; Jonsson et al. 2009). Additional complexities arise when organic molecules interact with crystal surface irregularities (Teng and Dove 1997; Teng et al. 1998, 2000; Orme et al. 2001; De Yoreo and Dove 2004; Elhadj et al. 2006). Such interactions can be strikingly revealed during crystal growth or dissolution in the presence of organic molecules, which can preferentially dock along crystallographically distinct edges and kinks. Such binding may inhibit crystal growth in certain directions and thus result in unusual crystal morphologies (e.g., Teng et al. 2006). For example, Cody and Cody (1991) showed strikingly varied skewed growth of macroscopic gypsum $\left(\mathrm{CaSO}^{4} \mathrm{H}_{2} \mathrm{O}\right)$ crystals in the presence of 28 different chiral organic solutes, including amino acids and carboxylic acids. Such exquisite molecular control of crystal growth and orientation points to strategies for nano-engineering and underscores the intricacies of modeling real-world prebiotic organic selection and organization (De Yoreo and Dove 2004). 
R.M. Hazen

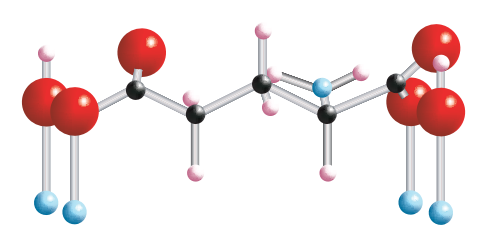

A

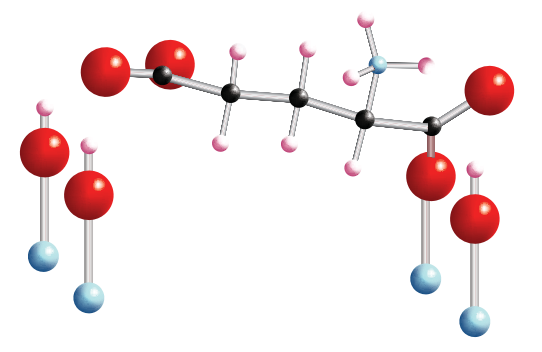

C

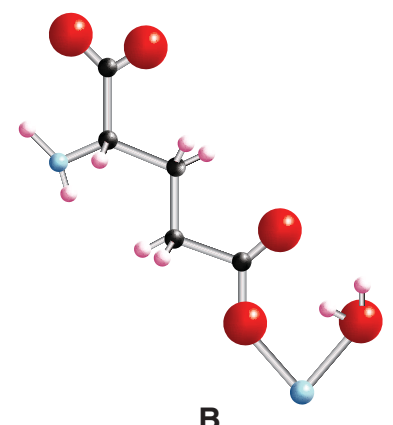

B

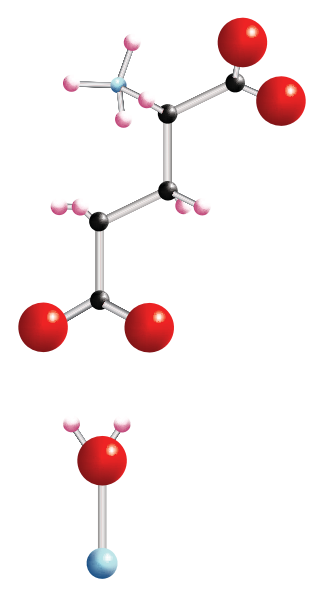

D

Figure 3. Amino acids bind in different ways to mineral surfaces. Numerous possible modes of attachment exist for glutamate adsorbed to rutile $\left(\mathrm{TiO}_{2}\right)$ surface sites, consistent with surface complexation calculations (Sverjensky et al. 2008; Jonsson et al. 2009). Large red spheres indicate oxygen atoms, small black spheres carbon, small pink or blue spheres hydrogen or nitrogen, respectively, and the lowermost blue spheres titanium at the rutile surface. (A) Bridging-bidentate species with four points of attachment involving one inner-sphere $\mathrm{Ti}-\mathrm{O}-\mathrm{C}$ bond and one $\mathrm{Ti}-\mathrm{OH} . . \mathrm{O}=\mathrm{C}$ hydrogen bond for each carboxylate. $(B)$ Chelating species with two points of attachment involving one inner-sphere Ti-O-C bond and one $\mathrm{Ti}-\mathrm{OH}_{2}^{+} \ldots \mathrm{O}=\mathrm{C}$ to a single titanium. $(C)$ Alternative to the bridging-bidentate species in $(A)$. This bridging-bidentate species has four points of attachment involving one inner-sphere Ti-O-C bond and one Ti-OH. . $\mathrm{O}=\mathrm{C}$ hydrogen bond of the a-carboxylate, and one Ti-OH... ${ }^{-} \mathrm{O}-\mathrm{C}$ hydrogen bond and one Ti-OH. . O $=\mathrm{C}$ hydrogen bond of the g-carboxylate (stabilized through resonance). (D) Alternative to the chelating species in $(B)$, outer-sphere or hydrogen bonded to the surface. After Jonsson et al. 2009.

\section{Mineral Evolution}

Any consideration of minerals and the origins of life must take into account which mineral species were available on the Hadean Earth. Recent studies have shown that the diversity and distribution of minerals at or near Earth's surface has changed dramatically over geological time (Hazen et al. 2008). Perhaps two-thirds of the approximately 4400 known mineral species represent weathering products owing to a biologically oxidized atmosphere, and thus are the indirect consequence of life. The nature and abundances of hydroxides, zeolites, and clay minerals, which are often invoked in origins-of-life models, were undoubtedly 
very different from today (Schoonen et al. 2004; Hazen et al. 2008). Many other minerals that concentrate rare pegmatophile elements such as $\mathrm{Li}, \mathrm{Be}, \mathrm{Cs}, \mathrm{Ta}$, and $\mathrm{U}$ may have taken a billion years or more to form, and so their first appearances would have postdated the origins of life (Grew and Hazen 2009; Hazen et al. 2009). Thus, origin-of-life scenarios that invoke rare or exotic minerals such as uraninite $\left(\mathrm{UO}_{2}\right)$ (Adam 2007) or colemanite $\left[\mathrm{Ca}_{2} \mathrm{~B}_{6} \mathrm{O}_{11} 5\left(\mathrm{H}_{2} \mathrm{O}\right)\right]$ (Ricardo et al. 2004) may be untenable.

\section{RECENT RESULTS}

The first emergent step in life's origin, the prebiotic synthesis of biomolecules, is also the best understood. Since the pioneering synthesis studies of Stanley Miller and Harold Urey (Miller 1953; Miller and Urey 1959; see also Wills and Bada 2000), facile production of organic molecules has been shown for several plausible prebiotic environments (Chyba and Sagan 1992; Lahav 1999; Fry 2000; Hazen 2005). More problematic is the second emergent step by which life's idiosyncratic subset of biomolecules was selected and then concentrated from the dilute, diverse suite of prebiotic molecular species that must have accumulated in the primitive oceans.

Consider, for example, the problem of amino acids. More than 70 different amino acids have been extracted from the Murchison meteorite and other carbonaceous chondrites (Cronin and Chang 1993; Sephton 2002; Pizzarello and Weber 2004; Pizzarello 2006; Martins 2007). This inventory, moreover, contains a mixture of both left- and right-handed amino acids, although by some accounts concentration of L-amino acids exceeds D-amino acids in some meteorites (Pizzarello and Cronin 2000; Pizzarello 2006). Life, in contrast, uses only 20 principal amino acids and these molecules occur almost exclusively in their so-called "lefthanded" forms. Life's sugars, lipids, and polycyclic molecules show similar molecular selectivity (Nelson and Cox 2004; Hazen 2005). By what process did this molecular selection and concentration occur?

Mineral surfaces have long been recognized as having the potential to select and organize organic molecules in the path from geochemistry to biochemistry (Bernal 1951; Goldschmidt 1952; Lahav 1994). The following sections thus consider recent results on aspects of mineralmediated molecular synthesis, selection, and organization.

\section{Mineral-"Catalyzed" Organic Synthesis}

The synthesis of small organic molecules from inorganic precursors, including mineral-mediated synthesis, is perhaps the best understood aspect of life's origins. For example, recent experiments by several groups have shown production of ammonia from reactions of $\mathrm{N}_{2}$ or nitrate with a wide range of oxides or sulfides (Brandes et al. 1998, 2008; Schoonen and Xu 2001; Dorr et al. 2003); thiols from $\mathrm{CO}_{2}$ and sulfides (Heinen and Lauwers 1996); and amino acids and other compounds from $\mathrm{CO}$ or $\mathrm{CO}_{2}, \mathrm{NH}_{3}$, and $\mathrm{H}_{2} \mathrm{O}$ and sulfides (Nakajima et al. 1975; Huber and Wächtershäuser 1997, 2006; Schoonen et al. 1999; Cody et al. 2000, 2001, 2004). Transition metal oxide or sulfide minerals are not true catalysts in these reactions because the surface is altered; rather, the minerals participate as reactants through a redox couple, for example:

$$
\begin{aligned}
& \mathrm{CO}_{2}+\mathrm{FeS}+\mathrm{H}_{2} \mathrm{~S} \rightarrow \mathrm{HCOOH}+\mathrm{FeS}_{2} \\
&+\mathrm{H}_{2} \mathrm{O}(\text { e.g., Cody } 2004), \text { or } \\
& 4 \mathrm{Cu}_{2} \mathrm{O}+2 \mathrm{H}_{2} \mathrm{O}+\mathrm{NO}_{3}^{-} \rightarrow \mathrm{NH}_{3}+8 \mathrm{CuO}+\mathrm{OH}^{-}
\end{aligned}
$$

(Brandes et al. 2008).

Alternatively, many common minerals have been shown to catalyze carbon addition reactions, including Fischer-Tropsch-type synthesis and hydroformylation (Heinen and Lauwers 1996; McCollum et al. 1999; Cody et al. 2004). Varied roles of minerals in the synthesis of small organic molecules have been reviewed recently by Cody (2004) and Schoonen et al. (2004) and are not considered further here.

\section{Molecular Adsorption and Stabilization}

Experimental and theoretical investigations have documented the nature of molecular adsorption 
R.M. Hazen

for numerous mineral-molecule combinations (e.g., Lambert 2008; Lambert et al. 2009). Dozens of recent studies reveal complexity in structure and speciation of adsorbed organics, particularly through in situ FTIR and other spectroscopic studies (Somasundaran and Krishnakumar 1994; Rodriguez et al. 1996; Holmen et al. 1997; Roddick-Lanzilotta et al. 1998; Fitts et al. 1999; Klug and Forsling 1999; Kubicki et al. 1999; Roddick-Lanzilotta and McQuillan 1999, 2000; Duckworth and Martin 2001; Sheals et al. 2002; Lackovic et al. 2003; Rosenqvist et al. 2003; Yoon et al. 2004, 2005; Johnson et al. 2004a, 2004b, 2004c, 2005a, 2005b; Trout and Kubicki 2004; Persson and Axe 2005; Perezgasga et al. 2005; Benetoli et al. 2007; Arora and Kamaluddin 2009; Kitadai et al. 2009; Pászti and Guczi 2009). Important conclusions of these studies include the recognition of multiple adsorption configurations, including both single and multiple inner- and outer-sphere binding, for a given mineral-molecule pair.

Integration of experiments and theoretical molecular methods has been performed for amino acids on metal surfaces (Chen et al. 2002; Toomes et al. 2003; Efstathiou and Woodruff 2003; Barlow and Raval 2003; Jones and Baddeley 2004), for anions adsorbed on oxide surfaces (Collins et al. 1999; Kubicki et al. 1999; Kwon and Kubicki 2004; Peacock and Sherman 2004; Yoon et al. 2004; Bargar et al. 2005; Persson and Axe 2005), and for varied biomolecules on calcite (Thomas et al. 1993; Orme et al. 2001; Asthagiri and Hazen 2007). In addition, for the calcite-water interface, many theoretical simulations and observations exist to guide surface chemical models (Stipp and Hochella 1991; de Leeuw and Parker 1997, 1999; Teng et al. 1998, 2000; Fenter et al. 2000; Wright et al. 2001; Stipp 2002; de Leeuw and Cooper 2004; Geissbuhler et al. 2004; Kristensen et al. 2004).

Recent studies of organic anion adsorption on oxide surfaces show complex surface speciation: both inner- and outer-sphere species vary in relative importance over a range of $\mathrm{pH}$, ionic strength, and surface coverage. Many investigations document significant variations in proportions of inner- to outer-sphere species as a function of $\mathrm{pH}$ or surface coverage (e.g., Hug and Sulzberger 1994; Fitts et al. 1999; Nowack and Stone 1999; Roddick-Lanzilotta and McQuillan 2000; Lackovic et al. 2003; Sheals et al. 2003; Persson and Axe 2005). Proton titrations of oxide surfaces in electrolyte solutions, both with and without an organic adsorbate, provide powerful constraints on the possible reactions responsible for adsorption, particularly when used in combination with in situ attenuated total reflection Fourier transform infrared (ATR-FTIR) studies (Holman and Casey 1996; Nordin et al. 1997; Boily et al. 2000a, 2000b, 2000c, 2005; Sheals et al. 2002, 2003; Lackovic et al. 2003; Lindegren et al. 2005). However, with few exceptions (Gisler 1981; Whitehead 2003; Vlasova and Golovkova 2004; Vlasova 2005; Jonsson et al. 2009). Most adsorption studies of amino acids on oxide surfaces have been limited to systems without control of $\mathrm{pH}$ and ionic strength (e.g., Holm et al. 1983; Matrajt and Blanot 2004).

The work of Jonsson et al. (2009, 2010), who studied the adsorption of L-glutamate and L-aspartate on the surface of rutile $\left(\alpha-\mathrm{TiO}_{2}\right.$, $\left.\mathrm{pH}_{\mathrm{PZC}}=5.4\right)$ in $\mathrm{NaCl}$ solutions using potentiometric titrations and batch adsorption experiments over a wide range of $\mathrm{pH}$, ligandto-solid ratio, and ionic strength, illustrates the need for such integrated studies. Not only did they find that adsorption depends strongly on ionic strength and glutamate concentration, but the extended triple-layer surface complexation model of all the experimental results also indicated the existence of at least two surface glutamate complexes. For example, one possible mode of glutamate attachment involves a bridging-bidentate species binding through both carboxyl groups, which can be thought of as "lying down" on the surface (as found previously for amorphous titanium dioxide and hydrous ferric oxide) (Fig. 3A). Another adsorption mode involves a chelating species, which binds only through the $\gamma$-carboxyl group, i.e., "standing up" at the surface (Fig. 3B). The calculated proportions of these two surface glutamate species vary strongly, particularly with $\mathrm{pH}$ and glutamate concentration (Fig. 4). Any model of prebiotic interactions between mineral surfaces 
Mineral Surfaces

A

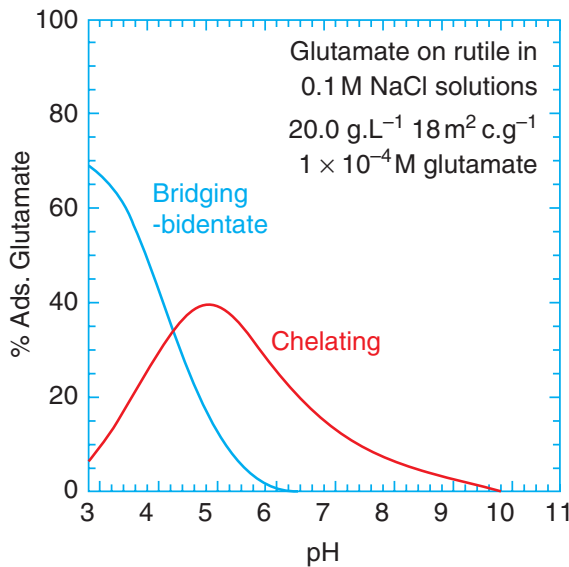

C

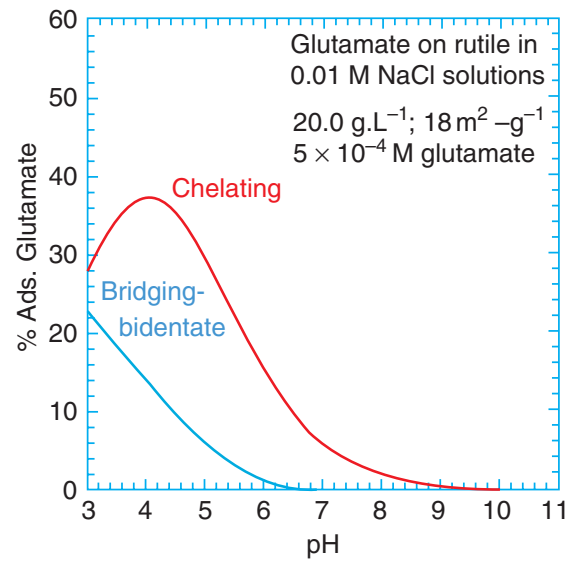

B

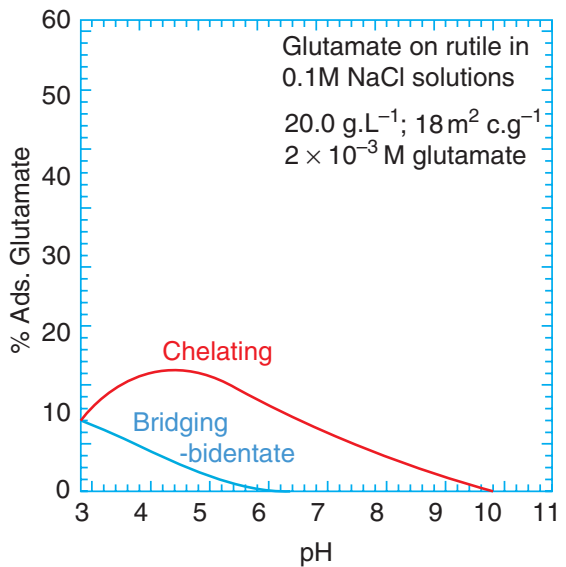

D

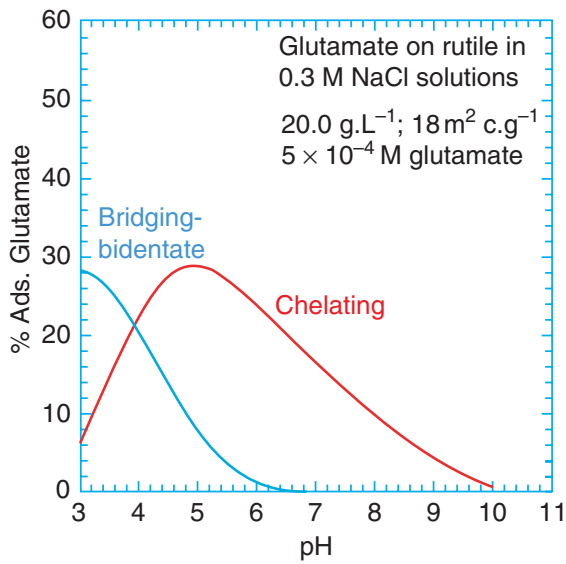

Figure 4. Predicted surface speciation of glutamate on rutile as a function of environmental conditions. The species names refer to the pictures in Figure 3. After Jonsson et al. 2009.

and biomolecules must take these added complexities into account.

\section{Chiral Molecular Adsorption}

A key attribute of life, and an important consideration in origins-of-life models, is life's molecular handedness, or chirality. Chiral crystalline surfaces provide effective environments for discrimination of left- and right-handed molecules in both natural and industrial contexts (Hazen and Sholl 2003). A chiral crystal surface is defined as any terminal arrangement of atoms that cannot be superimposed on its reflection in a mirror perpendicular to the surface. Such surfaces have long been cited in reference to their possible role in the origins of biochemical homochirality (Tsuchida et al. 1935; Karagounis and Coumoulos 1938; Amariglio et al. 1968; Bonner et al. 1975; Lahav 1999; Hazen et al. 2001). More recently, these crystal surfaces have received attention for their potential applications in the selection and purification of chiral pharmaceuticals and other molecular products (Soai et al. 1999; Kahr and Gurney 2001; Jacoby 2002; Rouhi 2004).

Most studies have focused on the behavior of chiral surfaces of cubic close-packed (CCP) metals, including copper, silver, gold, and platinum. Theoretical studies of these metal surfaces have shown the potential for significant differences in adsorption energies of right- versus 
R.M. Hazen

left-handed molecules (McFadden et al. 1996; Sholl 1998; Šljivančanin et al. 2002), whereas experiments provide indirect evidence for chiral selectivity (Ahmadi et al. 1999; Attard 2001; Sholl et al. 2001; Horvath and Gellman 2001, 2002; Kühnle et al. 2002). Less attention has been devoted to the wide variety of chiral oxide and silicate mineral surfaces, which are ubiquitous in Earth's crust. Such surfaces provide the most abundant and accessible local chiral geochemical environments, and thus represent logical sites for the prebiotic chiral selection and organization of essential biomolecules (Hazen and Sholl 2003; Hazen 2004, 2005, 2006; CastroPuyana et al. 2008). Hazen et al. (2001) first showed chiral-selective mineral adsorption, specifically of aspartate on the common $(21-34)$ surfaces of calcite $\left(\mathrm{CaCO}_{3}\right)$, whereas alanine displayed no such selection. Subsequent calculations (Asthagiri et al. 2004; Hazen 2006; Asthagiri and Hazen 2007) rationalize these results by demonstrating that aspartate, but not alanine, binds to the calcite surface with three noncolinear attachments (Fig. 5) - a prerequisite for chiral selection (Davankov 1997).

Numerous other common rock-forming minerals, including quartz $\left(\mathrm{SiO}_{2}\right)$, alkali feldspar $\left[(\mathrm{Na}, \mathrm{K}) \mathrm{AlSi}_{3} \mathrm{O}_{8}\right]$, and clinopyroxene $\left[(\mathrm{Ca}, \mathrm{Mg}, \mathrm{Fe}) \mathrm{SiO}_{3}\right]$, possess chiral crystal surfaces (Hazen 2004). One or more of these minerals is present in most rocks in Earth's crust, as well as on the Moon, Mars, and other terrestrial bodies, so chiral crystal environments are correspondingly ubiquitous. Furthermore, any irregular mineral fracture surface will provide an additional variety of local chiral environments. These natural chiral surface environments occur in both left- and right-handed variants in approximately equal proportions (Frondel 1978; Evgenii and Wolfram 1978). Nevertheless, the widespread occurrence of local chiral environments provided the prebiotic Earth with innumerable sites for experiments in chiral selection and organizationexperiments that may have led, through a process of chiral amplification, to a fortuitous, selfreplicating homochiral entity (Bonner 1991, 1995; Lippmann and Dix 1999; Zepik et al. 2002; Klussman et al. 2006, 2007; Noorduin et al. 2008).

\section{Mineral-induced Polymerization}

Many of life's essential macromolecules, including proteins, carbohydrates, and DNA, form from water-soluble monomeric units-amino acids, sugars, and nucleic acids, respectively. Under some (but not all) conditions, these polymers tend to break down rather than form in an aqueous medium (Shock 1993). Mineral surfaces provide a means to concentrate and assemble these bio-monomers. Lahav et al. (1978) showed that amino acids concentrate and polymerize on clay minerals to form small, proteinlike molecules. Such reactions occur when a solution containing amino acids evaporates in
A

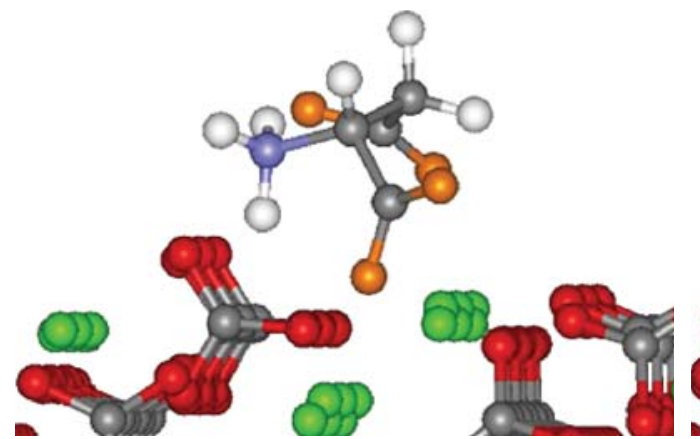

B

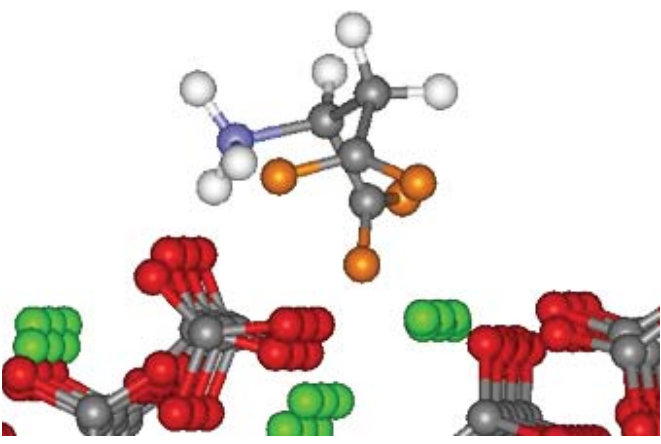

Figure 5. The most stable configurations for $\mathrm{L}^{-}$and $\mathrm{D}$-aspartate on the calcite $(21-34)$ surface $(A$ and $B$, respectively). The $\mathrm{D}$ enantiomer, which requires significantly less calcite surface relaxation and aspartate distortion, is favored by $8 \mathrm{Kcal} / \mathrm{mol}$ - the largest known enantiospecific effect. 
the presence of clays-a situation not unlike the evaporation that might have repeatedly dried up shallow prebiotic ponds or tidal pools. Numerous subsequent studies have elucidated the adsorption and polymerization of amino acids on varied crystalline surfaces (Zamaraev et al. 1997; Hill et al. 1998; Liu and Orgel 1998; Lambert 2008; Lambert et al. 2009; Rimola et al. 2009).

Ferris and colleagues (Holm et al. 1993; Ferris et al. 1996; Ertem and Ferris 1996, 1997; Ertem 2002; Ferris 1999, 2005; Ertem et al. 2007, 2008) induced clays to act as scaffolds in the formation of RNA oligomers up to 50-mers. Despite these advances, Orgel (1998) concluded that as more molecules are added to a lengthening polymer the strand becomes more tightly bound to the mineral surface. Such strong adhesion might prove problematic in the production of useful biologically active macromolecules. One possible solution was described by Hanczyc et al. (2003), who mixed clays, RNA nucleotides, and lipids in a single experiment. The clays adsorb RNA while hastening the formation of lipid vesicles. In the process, RNA-decorated clay particles are incorporated into the vesicles. This spontaneous selfassembly of RNA-containing vesicles represents a plausible pathway to the emergence of a selfreplicating cell-like entity.

Smith and coworkers (Smith 1998; Parsons et al. 1998; Smith et al. 1999) have explored an alternative to adsorption on clays by invoking reactions within the channels of mesoporous zeolite minerals. Prebiotic molecules concentrated and aligned inside zeolite channels might undergo polymerization reactions.

The most elaborate mineral-based origins scenario posits that self-replicating clay minerals were, themselves, the first living entities (CairnsSmith 1968, 1977, 1982, 1985a, 1985b, 1988; Cairns-Smith and Hartman 1986). According to this model, crystal growth defects, aperiodic cation distributions, or random layer stacking sequences constitute a kind of genetic information, analogous to the sequence of nucleotides (A, T, G, and C) in DNA. Cairns-Smith speculated that clay minerals could "replicate" by cleaving, whereas more favorable (i.e., stable) sequences evolve at the expense of less favorable sequences through the selective processes of growth and dissolution of individual particles. Ultimately, according to this hypothesis, organic molecules used clay-life as scaffolding for the evolution of modern biochemistry. Greenwell and Coveney (2006) have proposed a similar model using layered double hydroxides as "information storage and transfer compounds." Recent tests of the crystal gene model by Bullard and coworkers (2007) underscore the experimental difficulties inherent in testing such a model.

\section{CHALLENGES AND FUTURE RESEARCH DIRECTIONS}

A central objective of this collection is to move away from classical chemical scenarios that emphasize synthesis of simple organic molecules, and instead treat the origin of life as a pathway extending from the smallest organic molecules to the emergence of molecular systems that can be contained in some form of semi-permeable compartment. An important added emphasis is the consideration of realistic physical and chemical environments of early Earth. Life's origins occurred in a geochemical milieu in which chemically complex constituents at solidfluid and fluid-fluid interfaces were subjected to chemical and thermal gradients, fluid fluxes, and a variety of cyclic processes.

Recent experiments underscore the potential for these geochemical complexities to enhance significantly organic reaction rates and pathways, as well as the rates and mechanisms of molecular selection, concentration, and self-organization. Thus, these nonequilibrium aspects of dynamic geochemical environments may have been critical to promoting key steps in prebiotic chemical evolution. This article has emphasized possible roles of mineral surfaces in such information transfer.

Opportunities in Mineral Surfaces Research

Studies of mineral-molecule interactions are still in their infancy, but several intriguing observations should inform future work.

1. Differential adsorption: It is well known that electrolytes, metals, and organic molecules compete for surface binding sites (e.g., Schindler 1990), but few studies have 
R.M. Hazen

addressed the question of competitive or cooperative biomolecular adsorption. For example, Pontes-Buarques et al. (2001) discovered that while adenosine monophosphate (AMP) alone does not easily adsorb onto pyrite $\left(\mathrm{FeS}_{2}\right)$ in the absence of divalent cations, the addition of acetate strongly enhances AMP binding. Such interactive molecular adsorption phenomena could have important implications for life's chemical origins.

Competitive adsorption may also play an important role. Churchill et al. (2004) observed that amino acid adsorption may be highly dependent on mineral surface charge. Quartz ( $\mathrm{pH}_{\mathrm{PZC}} \sim 2.8$ ) tends to adsorb amino acids most strongly when the mineral $\mathrm{pH}_{\mathrm{PZC}}$ and the isoelectric point ( $\mathrm{pI}$ ) of the amino acid differ significantly. Thus, quartz adsorbs lysine ( $\mathrm{pI}=9.74)$ more strongly than amino acids with lower pI (glycine, alanine, aspartate, glutamate, tyrosine, and leucine). In contrast, although calcite $\left(\mathrm{pH}_{\mathrm{PZC}}=9.5\right)$ interacts most strongly with aspartate $(\mathrm{pI}=$ $2.98)$ and glutamate $(\mathrm{pI}=3.08)$, it also adsorbs a variety of other amino acids with $6<$ pI $<10$. Calcite may thus represent a more plausible template than quartz for prebiotic selection and organization of homochiral polypeptides. Similarly, ribose is selectively concentrated on rutile from equimolar solutions of the isomeric pentose sugars: arabinose, lyxose, ribose, and xylose (Hazen 2006; Bielski and Tencer 2006; Cleaves et al. 2009). Additional competitive adsorption experiments, including studies that incorporate realistic sea water salinity, are needed, even though divalent cations in solution may inhibit molecular self-organization in some systems (Monnard et al. 2002).

2. Molecular Organization: In the special case of highly planar crystal surfaces, it is sometimes possible to image individual adsorbed molecules or clusters of molecules. In some cases, adsorbed molecules have been found to organize into periodic two-dimensional surface structure-structures that might have played a role in prebiotic chemical evolution. Sowerby et al. (1996, 1998a, 1998b, 2002) used scanning tunneling microscopy to document structures of self-assembled monolayers of adenine and guanine on graphite (C) and molybdenite $\left(\mathrm{MoS}_{2}\right)$, Kühnle et al. (2002) imaged individual cysteine dimers adsorbed on gold, and Uchihashi et al. (1999) observed adenine adsorption on graphite with noncontact AFM. AFM studies and molecular calculations also suggest that amino acids can adsorb selectively along linear surface steps of calcite (Orme et al. 2001; de Yoreo and Dove 2004), perhaps providing an alignment conducive to homochiral polymerization (Hazen et al. 2001).

These results point to the need for in situ studies not just of adsorption, but also of molecular organization and polymerization on mineral surfaces. The potential roles of irregular surface topologies on polymerization (e.g., Elhadj et al. 2006) should also be explored.

3. Molecular Stabilization: A significant recurrent objection to any role of hydrothermal systems in life's origins is the rapid decomposition of many important biomolecules at elevated temperatures (Bada et al. 1995; Wills and Bada 2000; Bada and Lazcano 2002; see, however, Shock 1993; Seewald et al. 2006). However, inner-sphere bonding of organic molecules to mineral surfaces may play a significant role in enhancing the thermal stability of these molecules (Hazen 2006; Lambert 2008). For example, it is well known that the inner-sphere (calcium-oxygen) bonding of proteins such as osteocalcin and collagen to hydroxylapatite in bones (e.g., Hoang et al. 2004) can lead to the preservation of these proteins for periods in excess of a million years (Collins et al. 2000; Nielsen-Marsh et al. 2005; Schweitzer et al. 2007). Consequently, much more research needs to be performed on mineral-induced thermal stabilization of biomolecules.

\section{Experimental Design and the Origin of Life}

Perhaps the greatest challenge facing originsof-life researchers is conducting experiments 
that effectively mimic the complex prebiotic geochemical environment. Origins investigators have long recognized the importance of nonequilibrium characteristics of the prebiotic world and, accordingly, have incorporated some aspects of these geochemical realities into their experiments. The transformational experiments of Miller and Urey (Miller 1953; Miller and Urey 1959) used thermal gradients and fluid fluxes in association with spark discharges to achieve organic synthesis. Subsequent theoretical models (Wächtershäuser 1988, 1990, 1992; de Duve 1995; Russell and Hall 1997, 2006) and experiments (Lahav et al. 1978; Ferris et al. 1996; Huber and Wächtershäuser 1997; McCollum and Simoneit 1999; Whitfield 2009) have incorporated aspects of molecular complexity that may emerge from multi-component geochemical systems with gradients, fluxes, cycles, and interfaces. For example, Budin et al. (2009) have found that lateral thermal gradients in a narrow capillary environment enhance localized concentrations of lipids by orders of magnitudeconditions that foster vesicle formation in the low-temperature zones of the experiment.

Of special note are experiments in molecular evolution, for example of selectively binding RNA aptamers (Ellington and Szostak 1990; Wilson and Szostak 1999) and peptides (Seelig and Szostak 2007). These experiments incorporate chemical complexity, fluxes, interfaces, and cycles of molecular selection, each of which adds information to the system and quickly leads to highly functional molecules (Szostak 2003; Carothers et al. 2004; Hazen et al. 2007). Such selective, cycling environments likely represent an essential aspect of life's origins and evolution.

In the case of experiments on mineralmolecule interactions in an aqueous environment, most experiments to date have focused on a single well-characterized mineral with one solute in water with at most a single electrolyte at room conditions. Such experiments are essential to obtain baseline information on the magnitude and geometry of adsorption for various mineral-molecule pairs. Nevertheless, these studies do not replicate prebiotic complexities, including the multiple electrolytes of seawater, numerous competing organic species in the prebiotic soup, and numerous competing mineral phases and surfaces, all present over a range of temperature, pressure, $\mathrm{pH}$, and solute concentrations.

Added to these challenges are the daunting efforts required to reproduce nonequilibrium geochemical complexities in the laboratory. For example, any attempt to impose a thermal gradient on a chemical experiment adds at least three experimental variables $\left(\mathrm{T}_{\max }, \mathrm{T}_{\min }\right.$, and distance) that must be specified and controlled throughout an experiment. Imposition of cycles is even more challenging, for it requires control of experimental conditions for the two endmember states of the system, as well as the temporal variables related to cycle lengths and rates of change between these two states. Experiments to simulate geochemical environments in a closed laboratory system may encounter unanticipated problems. For example, initial attempts to mimic the interaction of mineralrich hydrothermal vents with colder ocean water at the Geophysical Laboratory and elsewhere have been thwarted, because metal sulfides dissolve in regions of hotter fluids and then precipitate and clog the system in cooler portions.

Nevertheless, despite the added experimental complexity of incorporating gradients, fluxes and cycles, these aspects of natural geochemical environments were probably essential to the emergence of biochemical complexity and thus must inform the design of future origins-of-life experiments.

\section{ACKNOWLEDGMENTS}

We thank R.J. Hemley for thoughtful comments and suggestions, David Deamer and Jack Szostak for spearheading this collection, and NASA's Astrobiology Institute, the National Science Foundation, the Alfred P. Sloan Foundation, and the Carnegie Institution of Washington for support of research on life's origins.

\section{REFERENCES}

Adam Z. 2007. Actinides and life's origins. Astrobiology 7: $852-872$.

Ahmadi A, Attard G, Feliu J, Rodes A. 1999. Surface reactivity at "chiral" platinum surfaces. Langmuir 15: 2420-2424. 
R.M. Hazen

Albarède F, Hoffmann AW. 2003. Geochemistry: An introduction. Cambridge University Press, Cambridge, UK.

Amariglio A, Amariglio H, Duval X. 1968. Asymmetric reactions on optically active quartz. Helv Chim Acta 51: 2110.

Arora AK, Kamaluddin. 2009. Role of metal oxides in chemical evolution: Interaction of ribose nucleotide with alumina. Astrobiology 9: 165-171.

Asthagiri A, Hazen RM. 2007. An ab initio study of adsorption of alanine on the chiral calcite (21-31) surface. Molec Sim 33: 343-351.

Asthagiri A, Downs RT, Hazen RM. 2004. Density functional theory modeling of interactions between amino acids and chiral mineral surfaces. Geol Soc Am Abstr with Prog (Denver CO):

Attard GA. 2001. Electrochemical studies of enantioselectivity at chiral metal surfaces. J Phys Chem B 105: 3158-3167.

Bada JL, Lazcano A. 2002. Some like it hot, but not the first biomolecules. Science 296: 1982-1983.

Bada JL, Miller SL, Zhao M. 1995. The stability of amino acids at submarine hydrothermal vent temperatures. Orig Life Evol Biosph 25: 111-118.

Bargar JR, Kubicki JD, Reitmeyer R, Davis JA. 2005. ATR-FTIR spectroscopic characterization of coexisting carbonate surface complexes on hematite. Geochim Cosmochim Acta 69: 1527-1542.

Barlow SM, Raval R. 2003. Complex organic molecules at metal surfaces: Bonding, organisation and chirality. Surf Sci Repts 50: 201-341.

Benetoli LOB, de Souza CMD, da Silva KL, de Souza IG Jr, de Santana H, Paesano A Jr, da Costa ACS, Zaia CTBV, Zaia DAM. 2007. Amino acid interaction with and adsorption on clays: FT-IR and Mossbauer spectroscopy and X-ray diffractometry investigations. Orig Life Evol Biosph 37: 479-493.

Bernal JD. 1951. The physical basis of life. Routledge and Kegan Paul, London, UK.

Bernstein MP, Dworkin JP, Sandford SA, Cooper GW, Allamandola LJ. 2002. Racemic amino acids from the ultraviolet photolysis of interstellar ice analogues. Nature 416: 401-403.

Bielski R, Tencer M. 2006. A possible path to the RNAWorld: Enantioselective and diastereoselective purification of ribose. Orig Life Evol Biosph 37: 167-175.

Biino GG, Mannella N, Kay A, Mun B, Fadley CS. 1999. Surface chemical characterization and surface diffraction effects of real margarite (001): An angle-resolved XPS investigation. Am Mineral 84: 629-638.

Boily J-F, Persson P, Sjöberg S. 2000a. Benzenecarboxylate complexation at the goethite-water interface: I. A mechanistic description of pyromellitate surface complexes from the combined evidence of infrared spectroscopy, potentiometry, adsorption data and surface complexation modeling. Langmuir 16: 5719-5729.

Boily J-F, Persson P, Sjöberg S. 2000b. Benzenecarboxylate complexation at the goethite-water interface: II. Linking IR spectroscopic observations to mechanistic-like surface complexation models. Geochim Cosmochim Acta 64: 3453-3470.

Boily J-F, Persson P, Sjöberg S. 2000c. Benzenecarboxylate complexation at the goethite-water interface: III. The significance of modelling parameters and the influence of particle surface area. J Colloid Interface Sci 227: 132140.

Boily J-F, Sjöberg S, Persson P. 2005. Structures and stabilities of $\mathrm{Cd}$ and $\mathrm{Cd}$-phthalate complexes at the goethitewater interface. Geochim Cosmochim Acta 69: 3219-3236.

Bonner WA. 1991. The origin and amplifi cation of biomolecular chirality. Orig Life Evol Biosph 21: 59-111.

Bonner WA. 1995. Chirality and life. Orig Life Evol Biosph 25: 175-190.

Bonner WA, Kavasmaneck PR, Martin FS, Flores JJ. 1974. Asymmetric adsorption of alanine by quartz. Science 186: $143-144$.

Bonner WA, Kavasmaneck PR, Martin FS, Flores JJ. 1975. Asymmetric adsorption by quartz: A model for the prebiotic origin of optical activity. Orig Life 6: 367-376.

Brandes JA, Hazen RM, Yoder HSJr. 2008. Inorganic nitrogen reduction and stability under hydrothermal conditions. Astrobiology 8: 1113-1126.

Brandes JA, Boctor NZ, Cody GD, Cooper BA, Hazen RM, Yoder HSJr. 1998. Abiotic nitrogen reduction on the early Earth. Nature 395: 365-367.

Brown GE Jr, Parks GA. 2001. Sorption of trace elements on mineral surfaces: Modern perspectives from spectroscopic studies, and comments on sorption in the marine environment. Int Geol Rev 43: 963-1073.

Brown GE Jr, Heinrich VE, Casey WH, Clark DL, Eggleston C, Felmy A, Goodman DW, Grätzel M, Maciel G, McCarthy MI, et al. 1998. Metal oxide surfaces and their interactions with aqueous solutions and microbial organisms. Chem Rev 99:77-174.

Budin I, Bruckner R, Szostak J. 2009. Formation of protocell-like vesicles in a thermal diffusion column. $J$ Am Chem Soc 131: 9628-9629.

Bullard T, Freudenthal J, Avagyan S, Kahr B. 2007. Tests of Cairn-Smith's 'crystals-as-genes' hypothesis. Faraday Disc 136: 231-245.

Cairns-Smith AG. 1968. The origin of life and the nature of the primitive gene. J Theor Biol 10: 53-88.

Cairns-Smith AG. 1977. Takeover mechanisms and early biochemical evolution. Biosystems 9: 105-109.

Cairns-Smith AG. 1982. Genetic takeover and the mineral origins of life. Cambridge University Press, Cambridge, UK.

Cairns-Smith AG. 1985a. Seven clues to the origin of life. Cambridge University Press, Cambridge, UK.

Cairns-Smith AG. 1985b. The first organisms. Sci Amer 252: 90-100.

Cairns-Smith AG. 1988. The chemistry of materials for artificial Darwinian systems. Int Rev Phys Chem 7: 209-250.

Cairns-Smith AG, Hartman H. 1986. Clay minerals and the origin of life. Cambridge University Press, Cambridge, UK.

Carl DM. Editor. 1995. Deep-sea hydrothermal vents. CRC Press, Boca Raton, FL.

Carothers JM, Oestreich SO, Davis JH, Szostak JW. 2004. J Am Chem Soc 126: 5130-5137. 
Carter PW. 1978. Adsorption of amino acids-containing organic matter by calcite and quartz. Geochim Cosmochim Acta 42: 1239-1242.

Castro-Puyana M, Salgado A, Hazen RM, Crego AL, Marina ML. 2008. Investigation of the enantioselective adsorption of 3-carboxy adipic acid on minerals by capillary electrophoresis. Electrophoresis 29: 1548-1555.

Chen Q, Frankel DJ, Richardson NV. 2002. Chemisorption induced chirality: Glycine on $\mathrm{Cu}\{110\}$. Surf Sci 497: $37-46$.

Churchill H, Teng H, Hazen RM. 2004. Measurements of $\mathrm{pH}$-dependent surface charge with atomic force microscopy: Implications for amino acid adsorption and the origin of life. Am Mineral 89: 1048-1055.

Chyba CF, Sagan C. 1992. Endogenous production, exogenous delivery, and impact-shock synthesis of organic molecules: An inventory for the origins of life. Nature 355: $125-132$.

Cleaves HJ, Jonsson CM, Jonsson CL, Sverjensky DA, Hazen RM. 2010. Adsorption of nucleic acid components on rutile $\left(\mathrm{TiO}_{2}\right)$ surfaces. Astrobiology (in press).

Cody GD. 2004. Transition metal sulfides and the origins of metabolism. Annu Rev Earth Planet Sci 32: 569-599.

Cody AM, Cody RD. 1991. Chiral habit modifications of gypsum from epitaxial like adsorption of stereo-specific growth inhibitors. J Cryst Growth 113: 508-529.

Cody GD, Boctor NZ, Brandes JA, Filley TR, Hazen RM, Yoder HSJr. 2004. Assaying the catalytic potential of transition metal sulfides for prebiotic carbon fixation. Geochim Cosmochim Acta 68: 2185-2196.

Cody GD, Boctor NZ, Filley TR, Hazen RM, Scott JH, Yoder HSJr. 2000. The primordial synthesis of carbonylated iron-sulfur clusters and the synthesis of pyruvate. Science 289: $1339-1342$.

Cody GD, Boctor NZ, Hazen RM, Brandes JA, Morowitz HJ Yoder HS Jr. 2001. Geochemical roots of autotrophic carbon fixation: Hydrothermal experiments in the system citric acid- $\mathrm{H}_{2} \mathrm{O}-( \pm \mathrm{FeS})-( \pm \mathrm{NiS})$. Geochim Cosmochim Acta 65: 3557-3576.

Cohn CA, Hansson TK, Larsson HS, Sowerby SJ, Holm NG. 2001. Fate of prebiotic adenine. Astrobiology 1: 477-480.

Collins CR, Ragnarsdottir KV, Sherman DM. 1999. Effect of inorganic and organic ligands on the mechanism of cadmium sorption to goethite. Geochim Cosmochim Acta 63: 2989-3002.

Collins MJ, Gernaey AM, Nielsen-Marsh CM, Vermeer C Westbroeck P. 2000. Slow rates of degradation of osteocalcin: green light for fossil bone protein? Geology 26: 1139-1142.

Cronin JR, Chang S. 1993. Organic matter in meteorites: Molecular and isotopic analyses of the Murchison meteorite. In The chemistry of life's origins (ed. JM Greenberg et al.), pp. 209-258. Kluwer, The Netherlands.

Cygan RT, Wright K, Fisler DK, Gale JD, Slater B. 2002. Atomistic models of carbonate minerals: Bulk and surface structures, defects, and diffusion. Molec Sim 28: 475-495.

Davankov VA. 1997. The nature of chiral recognition: Is it a three-point interaction? Chirality 9: 99-102.

Davis JA, Kent DB. 1990. Surface complexation modeling in aqueous geochemistry. In Mineral-water interface geochemistry (ed. MF Hochella Jr, AF White), Rev Mineral 23: 177-260.

Davis JA, Meece DE, Kohler M, Curtis GP. 2004. Approaches to surface complexation modeling of uranium (VI) adsorption on aquifer sediments. Geochim Cosmochim Acta 68: 3621-3642.

Deamer DW, Pashley RM. 1989. Amphiphilic components of the Murchison carbonaceous chondrite: Surface properties and membrane formation. Orig Life Evol Biosph 19: 21-38.

de Duve C. 1995. Vital dust: Life as a cosmic imperative. Basic Books, New York.

de Leeuw NH, Cooper TG. 2004. A computer modeling study of the inhibiting effect of organic adsorbates on calcite crystal growth. Crystal Growth Design 4: 123-133.

de Leeuw NH, Parker SC. 1997. Atomistic simulation of the effect of molecular adsorption of water on the surface structure and energies of calcite surfaces. J Chem Soc, Faraday Trans 93: 467-475.

de Leeuw NH, Parker SC, Harding JH. 1999. Molecular dynamics simulation of crystal dissolution from calcite steps. Phys Rev B 60: 13792-13799.

De Yoreo JJ, Dove PM. 2004. Shaping crystals with biomolecules. Science 306: 1301-1302.

Dobson CM, Ellison GB, Tuck AF, Vaida V. 2000. Atmospheric aerosols as prebiotic chemical reactors. Proc Natl Acad Sci 97: 11864-11868.

Dorr M, Kasbohrer J, Grunert R, Kreisel G, Brand WA, Werner RA, Geilmann H, Apfel C, Robl C, Weigand W. 2003. A possible prebiotic formation of ammonia from dinitrogen on iron oxide surfaces. Angew Chem Int Ed Engl 42: 1540-1543.

Downs RT, Hazen RM. 2004. Chiral indices of crystalline surfaces as a measure of enantioselective potential. $J$ Mol Catal 216: 273-285.

Drever JI. 1997. The geochemstry of natural waters. Prentice Hall, New York.

Duckworth OW, Martin ST. 2001. Surface complexation and dissolution of hematite by C1-C6 dicarboxylic acids at $\mathrm{pH}=5.0$. Geochim Cosmochim Acta 65: 4289-4301.

Dzombak DA, Morel FMM. 1990. Surface complexation modeling. Wiley, New York.

Efstathiou V, Woodruff DP. 2003. Characterization of the interaction of glycine with $\mathrm{Cu}(100)$ and $\mathrm{Cu}$ (111). Surf Sci 531: 304-318.

Ellington AE, Szostak JW. 1990. Selection in vitro of singlestranded DNA molecules that fold into specific ligand binding sites. Nature 346: 818-822.

Elhadj S, Salter EA, Wierzbicki A, De Yoreo JJ, Han N, Dove PM. 2006. Peptide controls growth on calcite mineralization: Polyaspartate chain length affects growth kinetics and acts as a stereochemical switch on morphology. Crystal Growth Design 6: 197-201.

Ertem G. 2002. Montmorillonite, oligonucleotides, RNA and the origin of life. Orig Life Evol Biosph 34: 549-570.

Ertem G, Ferris JP. 1996. Synthesis of RNA oligomers on heterogeneous templates. Nature 379: 238-240.

Ertem G, Ferris JP. 1997. Template-directed synthesis using the heterogeneous templates produced by montmorillonite 
R.M. Hazen

catalysis: A possible bridge between the prebiotic and RNA worlds. J Am Chem Soc 119: 7197-7201.

Ertem G, Hazen RM, Dworkin JP. 2007. Sequence analysis of trimer isomers formed by montmorillonite catalysis in the reaction of binary monomer mixtures. Astrobiology 7: 715-724.

Ertem G, Hazen RM, Snellinger AM, Dworkin JP, Johnston MV. 2008. Sequence- and region-selective formation of RNA-like oligomers by montmorillonite catalysis. Int J Astrobiology 7: 1-7.

Eschenmoser A. 1999. Chemical etiology of nucleic acid structure. Science 284: 2118-2124.

Efstathiou V, Woodruff DP. 2003. Characterization of the interaction of glycine with $\mathrm{Cu}(100)$ and $\mathrm{Cu}(111)$. Surf Sci 531: 304-318.

Evgenii K, Wolfram T. 1978. The role of quartz in the origin of optical activity on Earth. Orig Life Evol Biosph 30: 431-434.

Fenter P, Geissbühler P, DiMasi E, Srajer G, Sorenson LB, Sturchio NC. 2000. Surface speciation of calcite observed in situ by high-resolution X-ray reflectivity. Geochim Cosmochim Acta 64: 1221-1228.

Ferris JP. 1999. Prebiotic synthesis on minerals: bridging the prebiotic and RNA worlds. Biol Bull 196: 311-314.

Ferris JP. 2005. Mineral catalysis and prebiotic synthesis: montmorillonite-catalyzed formation of RNA. Elements 1: 145-149.

Ferris JP, Hill AR Jr, Liu R, Orgel LE. 1996. Synthesis of long prebiotic oligomers on mineral surfaces. Nature 381: $59-61$.

Fitts JP, Persson P, Brown GE Jr, Parks GA. 1999. Structure and bonding of $\mathrm{Cu}(\mathrm{II})$-glutamate complexes at the $\gamma-\mathrm{Al}_{2}$ $\mathrm{O}_{3}$-water interface. J Colloid Surface Sci 220: 133-147.

Fox SW, Harada K. 1958. Thermal copolymerization of amino acids to a product resembling protein. Science 128: 1214.

Frondel C. 1978. Characters of quartz fibers. Am Mineral 63: $17-27$.

Fry I. 2000. The emergence of life on Earth: A historical and scientific overview. Rutgers University Press, New Brunswick, NJ.

Geissbuhler P, Fenter P, DiMasi E, Srajer G, Sorensen LB, Sturchio NC. 2004. Three dimensional structure of the calcite-water interface by surface X-ray scattering. Surf Sci 573: 191-203.

Gellman AJ, Horvath JD, Buelow MT. 2001. Chiral single crystal surface chemistry. J Mol Catal A 167: 3-11.

Gisler A. 1981. Die adsorption von aminosauren an grenzflachen oxid-wasser. PhD Thesis, 124 pp., Universitat Bern.

Glamoclija M, Steele A, Fries M, Schieber J, Voytek MA, Cockell CS. 2009. Association of anatase $\left(\mathrm{TiO}_{2}\right)$ amd microbes: unusual fossilization effect or a potential biosignature? In The ICDP-USGS Deep Drilling Project in the Chesapeake Bay Impact Structure: Results from the Eyreville Core Holes (ed. Gohn GS, et al.) Geol Soc Am Spec Pap 458: 965-975.

Goldschmidt VM. 1952. Geochemical aspects of the origin of complex organic molecules on the earth, as precursors to organic life. New Biol 12: 97-105.
Greenwell HC, Coveney PV. 2006. Layered double hydroxide minerals as possible prebiotic information storage and transfer compounds. Orig Life Evol Biosph 36: 13-37.

Grew ES, Hazen RM. 2009. Evolution of the minerals of beryllium: a quintessential crustal element [abstract]. Geol Soc Am Abstr with Prog (Portland OR).

Guevremont JM, Strongin DR, Schoonin MAA. 1998. Thermal chemistry of $\mathrm{H}_{2} \mathrm{~S}$ and $\mathrm{H}_{2} \mathrm{O}$ on the (100) plane of pyrite: unique reactivity of defect sites. Am Mineral 83: $1246-1255$.

Guevremont JM, Elsetinow AR, Strongin DR, Bebie J, Schoonen MAA. 1998. Structure sensitivity of pyrite oxidation: comparison of the (100) and (111) planes. Am Mineral 83: 1353-1356.

Hanczyc MM, Fujikawa SM, Szostak JW. 2003. Experimental models of primitive cellular compartments: encapsulation, growth, and division. Science 302: 618-622.

Hazen RM. 2004. Chiral crystal faces of common rockforming minerals. In Progress in Biological Chirality (Eds. G Palyi et al.), pp. 137-151. Elsevier, New York.

Hazen RM. 2005. Genesis: The scientific quest for life's origins. Joseph Henry Press, National Academy of Sciences, Washington, DC.

Hazen RM. 2006. Mineral surfaces and the prebiotic selection and organization of biomolecules. Am Mineral 91: 1715-1729.

Hazen RM, Sholl DS. 2003. Chiral selection on inorganic crystalline surfaces. Nature Mater 2: 367-374.

Hazen RM, Ewing RJ, Sverjensky DA. 2009. The evolution of uranium and thorium minerals. Am Mineral 94: $1293-1311$.

Hazen RM, Filley TR, Goodfriend GA. 2001. Selective adsorption of L- and D-amino acids on calcite: Implications for biochemical homochirality. Proc Natl Acad Sci 98: 5487-5490.

Hazen RM, Griffin P, Carothers J, Szostak J. 2007. Functional information and the emergence of biocomplexity. Proc Natl Acad Sci 104: 8574-8581.

Hazen RM, Papineau D, Bleeker W, Downs RT, Ferry JM, McCoy TJ, Sverjensky DA, Yang H. 2008. Mineral evolution. Am Mineral 93: 1693-1720.

Heinen W, Lauwers A-M. 1996. Organic sulfur compounds resulting from the interaction of iron sulfide, hydrogen sulfide and carbon dioxide in an anaerobic environment. Orig Life Evol Biosph 26: 131-150.

Hennet RJC, Holm NG, Engel MH. 1992. Abiotic synthesis of amino acids under hydrothermal conditions and the origin of life: a perpetual phenomenon? Naturwissenschaften 79: 361-365.

Hill ARJr, Böhler C, Orgel LE. 1998. Polymerization on the rocks: Negatively-charged $\alpha$-amino acids. Orig Life Evol Biosph 28: 235-242.

Hoang QQ, Sicheri F, Howard AJ, Yang DSC. 2003. Bone recognition mechanism of porcine osteocalcin from crystal structure. Nature 425: 977-980.

Hochella MF Jr. 1990. Atomic structure, microtopography, composition, and reactivity of mineral surfaces. In Mineral-water interface geochemistry, (ed. MF Hochella Jr, AF White), Rev Mineral 23: 87-132.

Hochella MF Jr. 1995. Mineral surfaces: their characterization and their physical and reactive nature. In Mineral 
surfaces (ed. DJ Vaughan, RAD Pattrick), pp. 17-60 Chapman and Hall, New York.

Hochella MF Jr, White AF. Editors. 1990. Mineral-Water Interface Geochemistry. Rev Mineral 23, Mineralogical Society of America, Chantilly, VA.

Hochella MFJr, Eggleston CM, Eilings VB, Thompson MS. 1990. Atomic structure and morphology of the albite (010) surface: an atomic-force microscopy and electron diffraction study. Am Mineral 75: 723-730.

Holm NG, Ertem G, Ferris JP. 1993. The binding and reactions of nucleotides and polynucleotides on iron oxide hydroxide polymorphs. Orig Life Evol Biosph 23: 195-215.

Holm NG, Dowler MJ, Wadsten T, Arrhenius G. 1983. $\beta$ - $\mathrm{FeOOH} . \mathrm{Cl}_{\mathrm{n}}$ (akaganite) and $\mathrm{Fe}_{1-\mathrm{x}} \mathrm{O}$ (wustite) in hot brine from the Atlantis II Deep (Red Sea) and the uptake of amino acids by synthetic $\beta$-FeOOH.Cl ${ }_{n}$. Geochim Cosmochim Acta 47: 1465-1470.

Holmen BA, Casey WH. 1996. Hydroxamate ligands, surface chemistry, and the mechanism of ligand-promoted dissolution of goethite $[\mathrm{FeOOH}(\mathrm{s})]$. Geochim Cosmochim Acta 60: 4403-4416.

Horvath JD, Gellman AJ. 2001. Enantiospecific desorption of R- and ZS-propylene oxide from a chiral $\mathrm{Cu}(643)$ surface. J Am Chem Soc 123: 7953-7954.

Horvath JD, Gellman AJ. 2002. Enantiospecific desorption of chiral compounds from chiral $\mathrm{Cu}$ (643) and achiral $\mathrm{Cu}$ (111) surfaces. J Am Chem Soc 124: 2384-2392.

Huber C, Wächtershäuser G. 1997. Activated acetic acid by carbon fixation on $(\mathrm{Fe}, \mathrm{Ni}) \mathrm{S}$ under primordial conditions. Science 276: 245-247.

Huber C, Wächtershäuser G. 2006. $\alpha$-hydroxy and $\alpha$ amino acids under possible Hadean, volcanic origin-oflife conditions. Science 314: 630-632.

Hug SJ, Sulzberger B. 1994. In situ Fourier transform infrared spectroscopic evidence for the formation of several different surface complexes of oxalate on $\mathrm{TiO}_{2}$ in the aqueous phase. Langmuir 10: 3587-3597.

Hung A, Yarovsky I, Russo SP. 2003. Density-functional theory studies of xanthate adsorption on the pyrite $\mathrm{FeS}_{2}$ (110) and (111) surfaces. JChem Phys 118: 6022-6029.

Jacoby M. 2002. 2-D stereoselectivity. Chem Eng News 80 (March 25, 2002): 43-46.

Johnson BB, Sjoberg S, Persson P. 2004a. Surface complexation of mellitic acid to goethite: An attenuated total reflection Fourier transform infrared study. Langmuir 20: $823-828$.

Johnson SB, Brown GE Jr, Healy TW, Scales PJ. 2005b. Adsorption of organic matter at mineral/water interfaces: 6 . Effect of inner-sphere versus outer-sphere adsorption on colloidal stability. Langmuir 21: 6356-6365.

Johnson SB, Yoon TH, Brown GE Jr. 2005a. Adsorption of organic matter at mineral/water interfaces: 5 . Effects of adsorbed natural organic matter analogues on mineral dissolution. Langmuir 21: 2811-2821.

Johnson SB, Yoon TH, Kokar BD, Brown GE Jr. 2004b. Adsorption of organic matter at mineral/water interfaces: 2 . Outer-sphere adsorption of maleate and implications for dissolution processes. Langmuir 20: 4996-5006.

Johnson SB, Yoon TH, Kokar BD, Brown GE Jr. 2004c. Adsorption of organic matter at mineral/water interfaces: 3 .
Implications of surface dissolution for adsorption of oxalate. Langmuir 20: 11480-11492.

Jones TE, Baddeley CJ. 2004. An investigation of the adsorption of $(R, R)$-tartaric acid on oxidised $\mathrm{Ni}\{111\}$ surfaces. $J$ Molec Catal A 216: 223-231.

Jonsson CM, Jonsson CL, Sverjensky DA, Cleaves HJ, Hazen RM. 2009. Attachment of L-glutamate to rutile $\left(\alpha-\mathrm{TiO}_{2}\right)$ : a potentiometric, adsorption and surface complexation study. Langmuir 25: 12127-12135.

Jonsson CM, Jonsson CL, Estrada C, Sverjensky DA, Cleaves HJ, Hazen RM. 2010. Adsorption of L-aspartate to rutile $\left(\alpha-\mathrm{TiO}_{2}\right)$ : experimental and theoretical surface complexation studies. Geochem Cosmochim Acta 74: 2356-2367.

Kahr B, Gurney RW. 2001. Dyeing crystals. Chem Rev 101: 893-951.

Karagounis G, Coumoulos G. 1938. A new method for resolving a racemic compound. Nature 142: 162-163.

Kelley DS, Karson JA, Früh-Green GL, Yoerger DR, Shank TM, Butterfield DA, Hayes JM, Schrenk MO, Olson EJ, Proskurowski G, et al. 2005. A serpentinite-hosted ecosystem: The Lost City hydrothermal field. Science 307: $1428-1434$.

Kitadai N, Yokoyama T, Nakashima S. 2009. ATR-IR spectroscopic study of L-lysine dsorption on amorphous silica. J Colloid Interface Sci 329: 31-37.

Klug O, Forsling W. 1999. A spectroscopic study of phthalate adsorption on $\gamma$-aluminum oxide. Langmuir 15: 69616868.

Klussmann M, Iwamura H, Mathew SP, Wells DHJr, Pandya U, Armstrong A, Blackmond DG. 2006. Thermodynamic control of asymmetric amplification in amino acid catalysis. Nature 441: 621-623.

Klussmann M, Izumi T, White AJ, Armstrong A, Blackmond DG. 2007. Emergence of solution-phase homochirality via engineering of amino acids. J Am Chem Soc 129: 7657-7660.

Koretsky CM, Sverjensky DA, Sahai N. 1998. A model of surface site types on oxide and silicate minerals based on crystal chemistry: Implications for site types and densities, multi-site adsorption, surface infrared spectroscopy, and dissolution kinetics. Am J Sci 298: 349-438.

Kornberg A, Rao NN, Ault-Riché D. 1999. Inorganic polyphosphate: A molecule of many functions. Annu Rev Biochem 68: 89-125.

Kristensen K, Stipp SLS, Refson K. 2004. Modeling steps and kinks on the surface of calcite. J Chem Phys 121: 8511-8523.

Kubicki JD, Schroeter LM, Itoh MJ. 1999. Attenuated total reflectance Fouriertransform infrared spectroscopy of carboxylic acids adsorbed onto mineral surfaces. Geochim Cosmochim Acta 63: 2709-2725.

Kühnle A, Linderoth TR, Hammer B, Besenbacher F. 2002. Chiral recognition in dimerization of adsorbed cysteine observed by scanning tunneling microscopy. Nature 415: 891-893.

Kwon K, Kubicki JD. 2004. Molecular orbital study on surface complex structures of phosphates to iron hydroxides: Calculation of vibrational frequencies and adsorption energies. Langmuir 20: 9249-9254. 


\section{R.M. Hazen}

Lackovic K, Angove MJ, Johnson BB, Wells JD. 2004 Modeling the adsorption of Cd(II) onto goethite in the presence of citric acid. J Colloid Interface Sci 267: 49-59.

Lackovic K, Johnson BB, Angove MJ, Wells JD. 2003. Modeling the adsorption of citric acid onto Muloorina illite and related clay minerals. J Colloid Interface Sci 267: 49-59.

Lahav N. 1994. Minerals and the origin of life: Hypotheses and experiments in heterogeneous chemistry. Hetreo Chem Rev 1: 159-179.

Lahav N. 1999. Biogenesis: Theories of life's origins. Oxford University Press, New York.

Lahav N, White D, Chang S. 1978. Peptide formation in the prebiotic era: Thermal condensation of glycine in fluctuating clay environments. Science 201: 67-69.

Lambert J-F. 2008. Adsorption and polymerization of amino acids on mineral surfaces: a review. Orig Life Evol Biosph 38: 211-242.

Lambert J-F, Stievano L, Lopes I, Gharsallah, Piao L. 2009. The fate of amino acids adsorbed on mineral matter. Planet Space Sci 57: 460-467.

Langel W, Menken L. 2003. Simulation of the interface between titanium oxide and amino acids in solution by first principles MD. Surf Sci 538: 1-9.

Langmuir D. 1997. Aqueous environmental geochemistry. Prentice-Hall, New York.

Lasaga AC. 1990. Atomic treatment of mineral-water surface reactions. In Mineral-water interface geochemistry (ed. MF Hochella Jr, AF White), Rev Mineral 23: 17-85.

Lasaga AC, Holland HD, Dwyer MJ. 1971. Primordial oil slick. Science 174: 53-55.

Lee H, Lee BP, Messersmith PB. 2007. A reversible wet/dry adhesive inspired by mussels and geckos. Nature 448: $338-342$.

Lee H, Scherer NF, Messersmith PB. 2006. Single-molecule mechanics of mussel adhesion. Proc Natl Acad Sci 103: 12999-13003.

Lindegren M, Loring JS, Redden G, Persson P. 2005. Citrate adsorption at the water-goethite interface: a spectroscopic evaluation of surface complexes. Goldschmidt Conf Abstr (Idaho), A369.

Lippmann DZ, Dix J. 1999. Possible mechanisms for spontaneous production of enantiomeric excess. In Advances in biochirality (ed. G Pályi, et al.), 85-98. Elsevier, New York.

Liu R, Orgel LE. 1998. Polymerization on the rocks: $\beta$-amino acids and arginine. Orig Life Evol Biosph 28: $245-257$.

Lorenzo MO, Baddeley CJ, Muryn C, Raval R. 2000. Extended surface chirality from supramolecular assemblies of adsorbed chiral molecules. Nature 404: 376-379.

Lowenstam HA, Weiner S. 1989. On biomineralization. Oxford University Press, New York.

Marshall WL. 1994. Hydrothermal synthesis of amino acids. Geochim Cosmochim Acta 58: 2099-2106.

Martin ZCTP. 2007. Chemical analysis of organic molecules in carbonaceous meteorites. PhD Thesis, Lisbon University, Portugal.
Matrajt G, Blanot D. 2004. Properties of synthetic ferrihydrite as an amino acid adsorbent and a promoter of peptide bond formation. Amino Acids 26: 153-158.

McCollum TM, Ritter G, Simoneit BR. 1999. Lipid synthesis under hydrothermal conditions by Fischer-Tropsch-type reactions. Orig Life Evol Biosph 29: 153-166.

McCollom TM, Simoneit BRT. 1999. Abiotic formation of hydrocarbons and oxygenated compounds during thermal decomposition of iron oxalate. Orig Life Evol Biosph 29: 167-186.

McFadden CF, Cremer PS, Gellman AJ. 1996. Adsorption of chiral alcohols on "chiral" metal surfaces. Langmuir 12: 2483-2487.

McSween HY, Richardson SM, Uhle M. 2003. Geochemistry: Pathways and processes, 2nd ed. Columbia University Press, New York.

Miller SL. 1953. A Production of amino acids under possible primitive Earth conditions. Science 117: 528-529.

Miller SL, Urey HC. 1959. Organic compound synthesis on the primitive Earth. Science 130: 245-251.

Monnard P-A, Apel CL, Kanavarioti A, Deamer DW. 2002. Influence of ionic inorganic solutes on self-assembly and polymerization processes related to early forms of life: Implications for a prebiotic aqueous medium. Astrobiology 2: 139-152.

Morowitz HJ. 1992. The beginnings of cellular life: metabolism recapitulates biogenesis. Yale University Press, New Haven, CT.

Morowitz HJ, Kostelnik JD, Yang J, Cody GD. 2000. The origins of intermediary metabolism. Proc Natl Acad Sci 97: 7704-7708.

Nakajima T, Yabushita Y, Tabushi I. 1975. Amino acid synthesis through biogenetic-type $\mathrm{CO}_{2}$ fixation. Nature 256: $60-61$.

Nelson DL, Cox MM. 2004. Lehninger's principles of biochemistry, 4th ed. Worth Publishers, New York.

Nielsen-Marsh CM, Richards MP, Hauschka PV, ThomasOates JE, Trinkaus E, Pettitt PB, Karavanic I, Poinar H, Collins MJ. 2005. Osteocalcin protein sequences of Neanderthals and modern primates. Proc Natl Acad Sci 102: 4409-4413.

Noorduin WL, Izumi T, Millemaggi A, Leeman M, Meekes H, Van Enckevort WJP, Kellogg RM, Kaptein B, Vlieg E, Blackmond DG. 2008. Emergence of a single solid chiral state from a nearly racemic amino acid derivative. J Am Chem Soc 130: 1158-1159.

Nordin J, Persson P, Laiti E, Sjoberg S. 1997. Adsorption of $o$-phthalate at the water-boehmite $(\gamma$-AlOOH $)$ interface: evidence for two coordination modes. Langmuir 13: 4085-4093.

Nowack B, Stone AT. 1999. Adsorption of phosphonates onto the goethite-water interface. J Colloid Interface Sci 214: $20-30$.

Oparin AI. 1938. The origin of life (S Morgulis, translator). Macmillan, New York.

Orgel LE. 1998. Polymerization on the rocks: Theoretical introduction. Orig Life Evol Biosph 28: 227-234.

Orme CA, Noy A, Wierzbicki A, McBride MT, Grantham M, Teng HH, Dove PM, DeYoreo JJ. 2001. Formation of chiral morphologies through selective binding of amino acids to calcite surface steps. Nature 411: 775-778. 
Oró J. 1961. Mechanism of synthesis of adenine from hydrogen cyanide under possible primitive Earth conditions. Nature 191: 1193-1194.

Parks GA. 1990. Surface energy and adsorption at mineralwater interfaces: An introduction. In Mineral-water interface geochemistry (ed. MF Hochella Jr, AF White), Rev Mineral 23: 133-175.

Parsons R. 1990. Electrical double layer: Recent experimental and theoretical developments. Chem Rev 90: 813-826.

Parsons I, Lee MR, Smith JV. 1998. Biochemical evolution II: Origin of life in tubular microstructures in weathered feldspar surfaces. Proc Natl Acad Sci 95: 15173-15176.

Pászti Z, Guczi L. 2009. Amino acid adsorption on hydrophilic $\mathrm{TiO}_{2}$ : a sum frequency generation vibrational spectroscopy study. Vib Spec 50: 48-56.

Peacock CL, Sherman DM. 2004. Vanadium adsorption onto goethite $(\mathrm{a}-\mathrm{FeOOH})$ at $\mathrm{pH} 1.5$ to 12 : a surface complexation model based on ab initio molecular geometries and EAFS spectroscopy. Geochim Cosmochim Acta 68: 1723-1733.

Perezgasga L, Serrato-Diaz A, Negron-Mendoza A, de Pablo Galan L, Mosqueira FG. 2005. Sites of adsorption of adenine, uracil, and their corresponding derivatives on sodium montmorillonite. Orig Life Evol Biosph 35: 91-110.

Persson P, Axe K. 2005. Adsorption of oxalate and malonate at the water-goethite interface: molecular surface speciation from IR spectroscopy. Geochim Cosmochim Acta 69: $541-552$.

Pinto JP, Gladstone GR, Yung YL. 1980. Photochemical production of formaldehyde in Earth's primitive atmosphere. Science 210: 183-185.

Pitsch S, Eschenmoser A, Gedulin B, Hui S, Arrhenius G 1995. Mineral induced formation of sugar phosphates. Orig Life Evol Biosph 25: 297-334.

Pizzarello S. 2006. The chemistry of life's origin: A carbonaceous meteorite perspective. Accounts of Chemical Research 39: 231-237.

Pizzarello S, Cronin JR. 2000. Non-racemic amino acids in the Murray and Murchison meteorites. Geochem Cosmochim Acta 64: 329-338.

Pizzarello S, Weber A. 2004. Prebiotic amino acids as asymmetric catalysts. Science 303: 1151.

Pontes-Buarques M, Tessis AC, Bonapace JA, Monte MBM, Cortés-Lopez G, de Souza-Barros F, Vieyra A. 2001. Modulation of adenosine $5^{\prime}$-monophosphate adsorption onto aqueous resident pyrite: potential mechanisms for prebiotic reactions. Orig Life Evol Biosph 31: 343-362.

Power TD, Sholl DS. 1999. Enantiospecific adsorption of chiral hydrocarbons on naturally chiral $\mathrm{Pt}$ and $\mathrm{Cu}$ surfaces. J Vac Sci Technol A 17: 1700-1704.

Ricardo A, Carrigan MA, Olcott AN, Benner SA. 2004. Borate minerals stabilize ribose. Science 303: 196-197.

Rimola A, Ugliengo P, Sodupe M. 2009. Formation versus hydrolysis of the peptide bond from a quantummechanical viewpoint: the role of mineral surfaces and implications for the origin of life. Int J Mol Sci 10: 746-760.

Roddick-Lanzilotta AD, McQuillan AJ. 1999. An in situ infrared spectroscopic investigation of lysine peptide and polylysine adsorption to $\mathrm{TiO}_{2}$ from aqueous solutions. J Colloid Interface Sci 217: 194-202.

Roddick-Lanzilotta AD, McQuillan AJ. 2000. An in situ infrared spectroscopic study of glutamic acid and of aspartic acid adsorbed on $\mathrm{TiO}_{2}$ : implications for the biocompatibility of titanium. J Colloid Interface Sci 227: $48-54$.

Roddick-Lanzilotta AD, Connor PA, McQuillan AJ. 1998. An in situ infrared spectroscopic study of the adsorption of lysine to $\mathrm{TiO}_{2}$ from an aqueous solution. Langmuir 14: 6479-6484.

Rodriguez R, Blesa MA, Regazzoni AE. 1996. Surface complexation at the $\mathrm{TiO}_{2}$ (anatase)/aqueous solution interface: chemisorptions of catechol. J Colloid Interface Sci 177: 122-131.

Rouhi AM. 2004. Chiral chemistry. Chem Eng News 82 (June 14, 2004): 47-62.

Rosenqvist J, Axe K, Sjöberg S, Persson P. 2003. Adsorption of dicarboxylates on nano-sized gibbsite particles: effects of ligand structure on bonding mechanism. Colloids Surfaces 220: 91-104.

Russell MJ, Hall AJ. 1997. The emergence of life from iron monosulphide bubbles at a submarine hydrothermal redox and pH front. J Geol Soc London 154: 377-402.

Sanchez R, Ferris J, Orgel LE. 1967. Studies in prebiotic synthesis. II. Synthesis of purine precursors and amino acids from aqueous hydrogen cyanide. J Molec Biol 30: 223-253.

Schindler PW. 1990. Co-adsorption of metal ions and organic ligands: formation of ternary surface complexes. In Mineral-Water Interface Geochemistry (ed. MF Hochella Jr, AF White), Rev Mineral 23: 281-307.

Schoonen MAA, Xu Y. 2001. Nitrogen reduction under hydrothermal vent conditions: Implications for the synthesis of C-H-O-N compounds. Astrobiology 1: 133-140.

Schoonen MAA, Xu Y, Bebie J. 1999. Energetics and kinetics of the prebiotic synthesis of simple organic acids and amino acids with the $\mathrm{FeS} / \mathrm{FeS}_{2}$ redox couple as reductant. Orig Life Evol Biosph 29: 5-32.

Schoonen MAA, Smirnov A, Cohn C. 2004. A perspective on the role of minerals in prebiotic synthesis. Ambio 33: 539-551.

Schweitzer MH, Suo Z, Avci R, Asara JM, Allen MA, Arce FT, Horner JR. 2007. Analyses of soft tissue from Tyrannosaurus rex suggest the presence of protein. Science 316: $277-280$.

Seelig B, Szostak JW. 2007. Selection and evolution of enzymes from a partially randomized non-catalytic scafford. Nature 448: $828-833$.

Seewald JS, Zolotov MY, McCollom T. 2006. Experimental investigation of single carbon compounds under hydrothermal conditions. Geochim Cosmochim Acta 70: 446-460.

Sephton MA. 2002. Organic compounds in carbonaceous meteorites. Natural Products Report 19: 292-311.

Shapiro R. 1988. Prebiotic ribose synthesis: a critical analysis. Orig Life Evol Biosph 18: 71-85.

Sheals J, Sjoberg S, Persson P. 2002. Adsorption of glyphosate on goethite: molecular characterization of surface complexes. Environ Sci Tech 36: 3090-3095. 


\section{R.M. Hazen}

Sheals J, Granstrom M, Sjoberg S, Persson P. 2003. Coadsorption of $\mathrm{Cu}$ (II) and glyphosate at the water-goethite $(\alpha-\mathrm{FeOOH})$ interface: molecular structures from FTIR and EXAFS measurements. J Colloid Interface Sci 262: $38-47$.

Shock EL. 1992. Chemical environments of submarine hydrothermal systems. Orig Life Evol Biosph 22: 67-107.

Shock EL. 1993. Hydrothermal dehydration of aqueous organic compounds. Geochim Cosmochim Acta 57: 3341-3349.

Sholl DS. 1998. Adsorption of chiral hydrocarbons on chiral platinum surfaces. Langmuir 14: 862-867.

Sholl DS, Asthagiri A, Power TD. 2001. Naturally chiral metal surfaces as enantiospecific adsorbents. J Phys Chem B 105: $4771-4782$

Sljivancanin Z, Gothelf KV, Hammer B. 2002. Density functional theory study of enantiospecific adsorption at chiral surfaces. J Am Chem Soc 124: 14789-14798.

Smith JV. 1998. Biochemical evolution. I. Polymerization on internal, organophilic silica surfaces of dealuminated zeolites and feldspars. Proc Natl Acad Sci 95: 3370-3375.

Smith JV, Arnold FP Jr, Parsons I, Lee MP. 1999. Biochemical evolution III: Polymerization on organophilic silica-rich surfaces, crystal-chemical modeling, formation of first cells, and geological clues. Proc Natl Acad Sci 96: 3479-3485.

Soai K, Osanai S, Kadowaki K, Yonekubo S, Shibata T, Sato I. 1999. d- and l-quartz-promoted highly enantioselective synthesis of a chiral organic compound. J Am Chem Soc 121: $11235-11236$.

Somasundaran P, Krishnakumar S. 1994. In situ spectroscopic investigations of adsorbed surfactant and polymer layers in aqueous and non-aqueous systems. Colloids Surfaces 93: 79-95.

Somorjai GA. 1994. Introduction to surface chemistry. Wiley, New York.

Sowerby SJ, Heckl WM, Petersen GB. 1996. Chiral symmetry breaking during the self assembly of monolayers from achiral purine molecules. J Molec Evol 43: 419-424.

Sowerby SJ, Edelwirth M, Heckl WM. 1998a. Self-assembly at the prebiotic solid-liquid interface: Structures of selfassembled monolayers of adenine and guanine bases formed on inorganic surfaces. J Phys Chem 102: $5914-$ 5922.

Sowerby SJ, Edelwirth M, Reiter M, Heckl WM. 1998b. Scanning tunneling microscopy image contrast as a function of scan angle in hydrogen-bonded self-assembled monolayers. Langmuir 14: 5195-5202.

Sowerby SJ, Petersen NG, Holm NG. 2002. Primordial coding on amino acids by adsorbed purine bases. Orig Life Evol Biosph 32: 35-46.

Steele JH, Thorpe SA, Turekian KK. Editors. 2009. Encyclopedia of ocean sciences, 2nd ed. Elsevier, Burlington, MA.

Stipp SL. 2002. Where the bulk terminates: Experimental evidence for restructuring, chemibonded $\mathrm{OH}_{-}$and $\mathrm{H}+$, adsorbed water and hydrocarbons on calcite surfaces. Molec Sim 28: 497-516.

Stipp SL, Hochella MF Jr. 1991. Structure and bonding environments at the calcite surface as observed with X-ray photoelectron spectroscopy (XPS) and low energy electron diffraction (LEED). Geochim Cosmochim Acta 55: 1723-1736.

Stribling R, Miller SL. 1987. Energy yields for hydrogen cyanide and formaldehyde synthesis: the $\mathrm{HCN}$ and amino acid concentrations in the primitive ocean. Orig Life 17: 261-273.

Stumm W. 1992. Chemistry of the solid-water interface. Wiley, New York.

Sverjensky DA. 2005. Prediction of surface charge on oxides in salt solutions: revisions for 1:1 $\left(\mathrm{M}^{+} \mathrm{L}^{-}\right)$electrolytes. Geochim Cosmochim Acta 69: 225-257.

Sverjensky DA, Fukushi K. 2006. Anion adsorption on oxide surfaces: Inclusion of the water dipole in modeling the electrostatics of ligand exchange. Environ Sci Tech 40: 263-271.

Sverjensky DM, Jonsson CM, Jonsson CL, Cleaves HJ, Hazen RM. 2008. Glutamate surface speciation on amorphous titanium dioxide and hydrous ferric oxide. Environ Sci Tech 42: 6034-6039.

Szostak J. 2003. Functional information. Nature 423: 689.

Teng HH, Dove PM. 1997. Surface site-specific interactions of aspartate with calcite during dissolution: Implications for biomineralization. Am Mineral 82: 878-887.

Teng HH, Chen Y, Pauli E. 2006. Direction specific interactions of 1,4-dicarboxylic acid with calcite surfaces. J Am Chem Soc 128: 14482-14484.

Teng HH, Dove PM, DeYoreo JJ. 2000. Kinetics of calcite growth: analysis of surface processes and relationships to macroscopic rate laws. Geochim Cosmochim Acta 64: 2255-2266.

Teng HH, Dove PM, Orme C, DeYoreo JJ. 1998. The thermodynamics of calcite growth: a baseline for understanding biomineral formation. Science 282: 724-727.

Thomas MM, Clouse JA, Longo JM. 1993. Adsorption of organic compounds on carbonate minerals. I. model compounds and their influence on mineral wettability. Chem Geol 109: 201-213.

Toomes RL, Kang J-H, Woodruff DP, Polcik M, Kittel M, Hoeft J-T. 2003. Can glycine form homochiral structural domains on low-index copper surfaces? Surface Science 552: L9-L14.

Trout CC, Kubicki JD. 2004. UV resonance Raman spectra and molecular orbital calculations of salicylic and phthalic acids complexed to $\mathrm{Al}(3+)$ in solution and on mineral surfaces. J Phys Chem A 108: 11580-11590.

Tuck A. 2002. The role of atmospheric aerosols in the origin of life. Surveys Geophys 23: 379-409.

Tsuchida R, Kobayashi M, Nakamura A. 1935. Asymmetric adsorption of complex salts on quartz. J Chem Soc Japan 56: 1339.

Turekian KK. 1968. Oceans. Prentice-Hall, New York.

Uchihashi T, Okada T, Sugawara Y, Yokoyama K, Morita S. 1999. Self-assembled monolayer of adenine base on graphite studied by noncontact atomic force microscopy. Phys Rev B 60: 8309-8313.

Van Cappellen P, Charlet L, Stumm W, Wersin P. 1993. A surface complexation model of the carbonate mineral-aqueous solution interface. Geochim Cosmochim Acta 57: 3505-3518. 
Van Dover CL. 2000. The ecology of deep-sea hydrothermal vents. Princeton University Press, Princeton, NJ.

Vaughan DJ. 1995. Mineral surfaces: an overview. In Mineral Surfaces, (ed. DJ Vaughan, RAD Pattrick), pp. 1-16. Chapman and Hall, New York.

Vlasova NN. 2005. Adsorption of copper-amino acid complexes on the surface of highly dispersed silica. Colloid J 67: 537-541.

Vlasova NN, Golovkova LP. 2004. The adsorption of amino acids on the surface of highly dispersed silica. Colloid J 66: 733-738.

Wächtershäuser G. 1988. Before enzymes and templates: theory of surface metabolism. Microbiol Rev 52: 452-484.

Wächtershäuser G. 1990. Evolution of the first metabolic cycles. Proc Natl Acad Sci 87: 200-204.

Wächtershäuser G. 1992. Groundworks for an evolutionary biochemistry: the iron-sulfur world. Prog Biophys Molec Biol 58: 85-201.

Weiner S, Addadi L. 1997. Design strategies in mineralized biological materials. J Mater Chem 7: 689-702.

Weissbuch I, Addadi L, Lahav M, Leiserowitz L. 1991. Molecular recognition at crystal interfaces. Science 253: 637-644.

Westheimer FH. 1987. Why nature chose phosphates. Science 235: 1173-1178.

Whitehead CF. 2003. (Amino)carboxylate coordination reactions with ferric (hydr)oxides: adsorption and ligand-assisted dissolution. PhD Thesis, 303 pp., Johns Hopkins University.

Whitfield J. 2009. Nascence man. Nature 459: 316-319.

Wills C, Bada JL. 2000. The spark of life: Darwin and the primeval soup. Perseus, Cambridge, MA.
Wilson DS, Szostak JW. 1999. In vitro selection of functional nucleic acids. Annu Rev Biochem 68: 611-647.

Wright K, Cygan RT, Slater B. 2001. Structure of the (10-14) surfaces of calcite, dolomite, and magnesite under wet and dry conditions. Phys Chem Chem Phys 3: 839-844.

Yoon TH, Johnson SB, Brown GE Jr. 2005. Adsorption of organic matter at mineral/water interfaces: IV. Adsorption of humic substances at boehmite/water interfaces and impact on boehmite dissolution. Langmuir 21: 5002-5012.

Yoon TH, Johnson SB, Musgrave CB, Brown GE Jr. 2004. Adsorption of organic matter at mineral/water interfaces: I. ATR-FTIR spectroscopic and quantum chemical study of oxalate adsorbed at boehmite/water and corundum/water interfaces. Geochim Cosmochim Acta 68: $4505-4518$.

Zaikowski L, Friedrich JM. Editors. 2007. Chemical Evolution across Space and Time. American Chemical Society Symposium Series, 981: 1-430.

Zamaraev KL, Romannikov VN, Salganik RI, Wlassof WA, Khramtsov VV. 1997. Modeling of the prebiotic synthesis of oligopeptides: silicate catalysts help to overcome the critical stage. Orig Life Evol Biosph 23: 325-337.

Zepik H, Shavit E, Tang M, Jensen TR, Kjaer K, Bolbach G, Leiserowitz L, Weissbuch I, Lahav M. 2002. Chiral amplification of oligopeptides in two-dimensional crystalline self-assemblies on water. Science 295: 1266-1269.

Zhang Z, Fenter P, Cheng L, Sturchio NC, Bedzyk MJ, Machesky ML, Wesolowski DJ. 2004. Model-independent X-ray imaging of adsorbed cations at the crystal-water interface. Surf Sci 554: L95-L100.

Zhao XY, Zhao RG, Yang WS. 2000. Scanning tunneling microscopy investigation of L-lysine adsorbed on $\mathrm{Cu}$ (001). Langmuir 16: 9812-9818. 


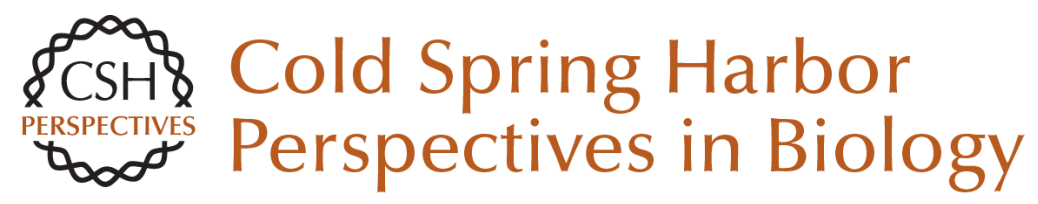

\section{Mineral Surfaces, Geochemical Complexities, and the Origins of Life}

Robert M. Hazen and Dimitri A. Sverjensky

Cold Spring Harb Perspect Biol 2010; doi: 10.1101/cshperspect.a002162 originally published online April 14,2010

\section{Subject Collection The Origins of Life}

Constructing Partial Models of Cells

Norikazu Ichihashi, Tomoaki Matsuura, Hiroshi Kita, et al.

Ribonucleotides John D. Sutherland

Deep Phylogeny--How a Tree Can Help

Characterize Early Life on Earth

Eric A. Gaucher, James T. Kratzer and Ryan N. Randall

Cosmic Carbon Chemistry: From the Interstellar Medium to the Early Earth Pascale Ehrenfreund and Jan Cami

Origin and Evolution of the Ribosome George E. Fox

Planetary Organic Chemistry and the Origins of Biomolecules Steven A. Benner, Hyo-Joong Kim, Myung-Jung Kim, et al.

Mineral Surfaces, Geochemical Complexities, and the Origins of Life

Robert M. Hazen and Dimitri A. Sverjensky

Historical Development of Origins Research Antonio Lazcano
The Hadean-Archaean Environment

Norman H. Sleep

An Origin of Life on Mars

Christopher P. McKay

Primitive Genetic Polymers

Aaron E. Engelhart and Nicholas V. Hud

Membrane Transport in Primitive Cells Sheref S. Mansy

The Origins of Cellular Life Jason P. Schrum, Ting F. Zhu and Jack W. Szostak

From Self-Assembled Vesicles to Protocells Irene A. Chen and Peter Walde

The Origin of Biological Homochirality Donna G. Blackmond

Earth's Earliest Atmospheres Kevin Zahnle, Laura Schaefer and Bruce Fegley

For additional articles in this collection, see http://cshperspectives.cshlp.org/cgi/collection/

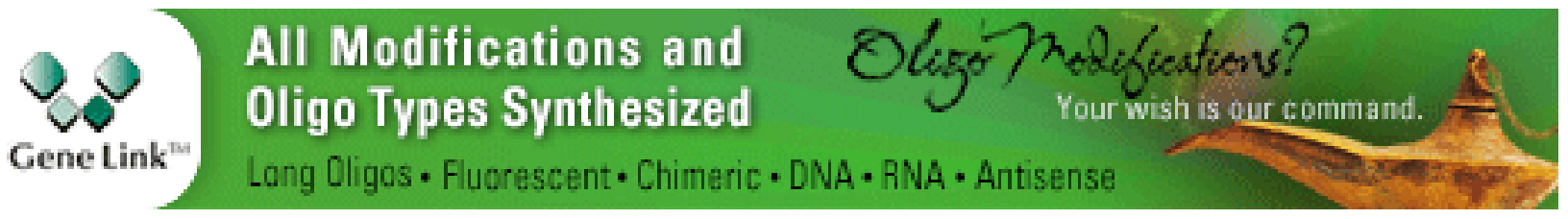

Copyright (C 2010 Cold Spring Harbor Laboratory Press; all rights reserved 